NBER WORKING PAPER SERIES

\title{
SAVINGS IN TRANSNATIONAL HOUSEHOLDS: A FIELD EXPERIMENT AMONG MIGRANTS FROM EL SALVADOR
}

\author{
Nava Ashraf \\ Diego Aycinena \\ Claudia Martínez A. \\ Dean Yang \\ Working Paper 20024 \\ http://www.nber.org/papers/w20024 \\ NATIONAL BUREAU OF ECONOMIC RESEARCH \\ 1050 Massachusetts Avenue \\ Cambridge, MA 02138 \\ March 2014
}

This paper was previously titled "Remittances and the Problem of Control." We thank the core members of the project team at ESSMF (Angela Gonzalez, Michelle Guevara, Ronald Luna, Amaris Rodriguez, and Eric Rubin), at FUSADES (Margarita Sanfeliu and Mauricio Shi), and at Banco Agricola (Hector Aguiar, Gustavo Denys, Carla de Espinoza, Mauricio Gallardo, Oscar Hernandez, Sabina Lopez, Ernesto Magana, Katya O'Byrne, and Paul Ponce). We greatly appreciate the collaboration of Enilson Solano and the El Salvador embassy in Washington DC. We received valuable feedback and suggestions from Manuel Agosin, Natasha Bajuk, Catia Batista, Charlie Brown, Michael Clemens, Angus Deaton, Esther Duflo, Suzanne Duryea, Jon Guryan, Ricardo Hausmann, Gabriela Inchauste, Takatoshi Kamezawa, Michael Kremer, Steve Levitt, John List, Adriana Lleras-Muney, Ernesto Lopez-Cordova, Osmel Manzano, Doug Massey, Margarita Mooney, Hugo Ñopo, Chris Paxson, Alejandro Portes, Jesse Rothstein, Jesse Shapiro, Ernesto Stein, Bryce Millett Steinberg, Mel Stephens, Don Terry, Steve Wilson, Viviana Zelizer, and participants in several seminars. Alejandra Aponte, Fernando Balzaretti, Sebastian Calonico, Carly Farver, Andres Shahidinejad, and Cristian Sanchez provided excellent research assistance. This research was made possible by financial support from the John D. and Catherine T. MacArthur Foundation, the Inter-American Development Bank, the National Science Foundation, the Multilateral Investment Fund, the Empowerment Lab at Harvard University's Center for International Development, and the University of Michigan's International Policy Center. Dean Yang acknowledges research support from National Science Foundation award SES-0851570. The views expressed herein are those of the authors and do not necessarily reflect the views of the National Bureau of Economic Research.

NBER working papers are circulated for discussion and comment purposes. They have not been peerreviewed or been subject to the review by the NBER Board of Directors that accompanies official NBER publications.

(C) 2014 by Nava Ashraf, Diego Aycinena, Claudia Martínez A., and Dean Yang. All rights reserved. Short sections of text, not to exceed two paragraphs, may be quoted without explicit permission provided that full credit, including (C) notice, is given to the source. 
Savings in Transnational Households: A Field Experiment among Migrants from El Salvador Nava Ashraf, Diego Aycinena, Claudia Martínez A., and Dean Yang

NBER Working Paper No. 20024

March 2014

JEL No. F22,O16

\begin{abstract}
We implemented a randomized field experiment that tested ways to stimulate savings by international migrants in their origin country. We find that migrants value and take advantage of opportunities to exert greater control over financial activities in their home countries. In partnership with a Salvadoran bank, we offered U.S.-based migrants bank accounts in El Salvador. We randomly varied migrant control over El Salvador-based savings by offering different types of accounts across treatment groups. Migrants offered the greatest degree of control accumulated the most savings at the partner bank, compared to others offered less or no control over savings. Impacts are likely to represent increases in total savings: there is no evidence that savings increases were simply reallocated from other savings mechanisms. Enhanced control over home-country savings does not affect remittances sent home by migrants.
\end{abstract}

Nava Ashraf
Harvard Business School
Baker Library 443
Soldiers Field
Boston, MA 02163
and NBER
nashraf@hbs.edu
Diego Aycinena
Universidad Francisco Marroquín
6a calle final zona 10
Edificio Académico, Oficina E-503
Ciudad de Guatemala
Guatemala
diegoaa@ufm.edu.gt

Claudia Martínez A.

Diagonal Paraguay 257

Oficina 1503-D

Departamento de Economía

Facultad de Economía y Negocios

Universidad de Chile

Santiago

Chile

cmartineza@econ.uchile.cl

Dean Yang

University of Michigan

Department of Economics and

Gerald R. Ford School of Public Policy

735 S. State Street, Room 3316

Ann Arbor, MI 48109

and NBER

deanyang@umich.edu 


\section{$\underline{\text { I. Introduction }}$}

Attempts to understand the extent and nature of conflict between household members are central to research on the economics of the family. Many empirical studies have cast serious doubt on the "unitary model" of the household, the proposition that the joint actions of a household comprised of separate optimizing individuals can be represented as the actions of a single utility-maximizing agent. ${ }^{1}$ Models that take explicit account of potential preference differences among household members include Manser and Brown (1980), McElroy and Horney (1981), and Lundberg and Pollak (1993). Browning and Chiappori (1998) provide empirical evidence rejecting the unitary model, but in favor of household efficiency in resource allocation. On the other hand, evidence of productive inefficiencies in intra-household allocation has been found in a variety of contexts. ${ }^{2}$

A leading candidate explanation for observed inefficiencies is asymmetry of information in the household, which reduces the ability of household members to enforce mutually-beneficial cooperative agreements among themselves. ${ }^{3}$ This idea has motivated new research that focuses on transnational households, or households with members who have migrated to other countries. Due to the absence of the migrant member, these are households where information asymmetries should be particularly pronounced. If migrants do not share the same financial objectives as family members remaining back home, information asymmetries may prevent migrants from achieving objectives that require the assistance or participation of relatives remaining in the home country. ${ }^{4}$

An improved understanding of financial decision-making within transnational households is important because flows of resources within such households are large in magnitude, and therefore may have important aggregate impacts. In 2011, migrant remittances sent to developing countries amounted to US\$353 billion. In comparison, in that year developing country receipts of foreign direct investment (the largest type of international financial flow going to the developing

\footnotetext{
${ }^{1}$ See the review in Strauss and Thomas (1995), as well as Duflo (2003), Rangel (2006), and Martinez (2013).

${ }^{2}$ See Udry (1996), Dercon and Krishnan (2000), Goldstein, de Janvry, and Sadoulet (2005), and Dubois and Ligon (2005), among others.

${ }^{3}$ Ashraf (2009) shows that individual saving decisions change when observed by one's spouse. Recent work on the savings and risk-sharing consequences of intra-household preference differences and asymmetric information includes Schaner (2011), Kinnan (2011), and Hertzberg (2011).

${ }^{4}$ In analyses of observational data, Chen (2006) and De Laat (2008) find empirical patterns consistent asymmetric information in migrant households, as evidenced by migrant monitoring of spouses in home areas (among domestic migrants in Kenya and China, respectively).
} 
world) were not quite double that figure (\$646 billion), while receipts of official development assistance (foreign aid) came in a poor third to remittances and FDI, amounting to just \$141 billion. ${ }^{5}$ International financial institutions and developing country governments are keenly interested in identifying policies that can enhance the development impacts of international migration and the accompanying resource flows. ${ }^{6}$

The substantial policy interest in remittances stands in stark contrast to the limited empirical evidence that can help guide policy. ${ }^{7}$ A number of questions related to decisionmaking in transnational households are of general economic interest, and policy-relevant. To what extent do migrants seek to monitor and control financial decision-making by household members remaining in the home country? What kinds of financial product innovations might enhance migrant ability to exert such monitoring and control? If given the opportunity to do so, would migrants seek to exert greater control over such decisions, and what would be the resulting impacts on financial decision-making in the transnational household?

To shed light on these questions, we conducted a randomized controlled trial among U.S.-based migrants from El Salvador. We randomized offers to migrants of financial products that varied the degree to which they could monitor and control savings in bank accounts in their home country. ${ }^{8}$ In survey data we collected, Salvadoran migrants report that they would like recipient households to save $21.2 \%$ of remittance receipts, while recipients prefer to save only $2.6 \%$ of receipts. Migrants often intend savings to be for future use by the recipient household, but such savings also can be intended for the migrants themselves. In the latter case, migrants may send their own funds to be saved in El Salvador because they perceive savings held in the U.S. to be relatively insecure (particularly for undocumented migrants who fear deportation and loss of their assets).

Migrants in the study were randomly assigned to a control group or to one of three treatment conditions that offered financial products with varying levels of monitoring and control over savings in El Salvador. We examine the effect on our outcomes of interest: take-up and

\footnotetext{
${ }^{5}$ Data on remittances, FDI, and ODA are from World Development Indicators 2013.

${ }^{6}$ Recent reports on remittances funded by the Inter-American Development Bank include Pew Hispanic Center (2002) and Terry and Wilson (2005). World Bank publications include World Bank (2006) and World Bank (2007).

${ }^{7}$ See Yang (2011) for a review of the state of research on the economics of migrant remittances.

${ }^{8}$ Chin, Wilcox, and Karkoviata (2010) conduct an experiment on savings among Mexican immigrants in Texas, finding that immigrants are more likely to open U.S. savings accounts, accumulate more savings in the U.S., and remit less to Mexico when they are helped obtain an I.D. that facilitates opening U.S. bank accounts.
} 
balances in savings accounts of various types. Our comparison group is referred to as Treatment 0 , and received no offer of any new financial products. In Treatment 1 , migrants were offered the opportunity to open a new account in the name of someone in El Salvador, into which the migrant could remit funds. This account allows the migrant to deposit but not to withdraw, nor to observe withdrawals. Treatment 2 offered the migrant the opportunity to open an account to be held jointly by the migrant and someone in El Salvador. This new joint account allows joint observability of account balances as well as joint withdrawals (both the migrant and the El Salvador person are given an ATM card for the account). Finally, in Treatment 3 migrants were offered, in addition to the accounts offered in Treatments 1 and 2, the option to open an account in the migrant's name only. ${ }^{9}$ Thus, each treatment nests the one prior to it so that the effect of offering additional products can be understood. Project staff delivered a marketing pitch for each product, according to its features. ${ }^{10}$ Data on financial transactions at our partner bank come from the bank's administrative records. Baseline and follow-up surveys administered to migrants in the U.S. provide data on other outcomes.

Our results provide evidence that migrants do value and take advantage of opportunities to exert control over savings in their home country. Migrants were much more likely to open savings accounts at the partner bank in El Salvador, and accumulated more savings at the partner bank, if they were assigned to the treatment condition offering the greatest degree of monitoring and control (Treatment 3). Migrants desire savings that are jointly held with family members, as well as savings only for themselves: we observe substantial increases in savings in both the joint accounts shared between migrants and someone in El Salvador (offered in Treatments 2 and 3), and in the accounts for migrants alone (offered only in Treatment 3). ${ }^{11}$ This increase in savings in the new accounts we offered is likely to be a true increase in savings; we find no evidence that these funds were simply shifted over from other types of savings (either from other accounts at the partner bank, or from other types of savings reported in the follow-up survey).

Strikingly, the impact of Treatment 1 (where we offered accounts in the name only of someone in El Salvador) on savings was much smaller in magnitude and not statistically

\footnotetext{
${ }^{9}$ In Treatments 2 and 3, upon request migrants would also have been allowed to open an account for someone in El Salvador only (the account offered in Treatment 1 ). No migrants made such a request.

${ }^{10}$ Moving from Treatments 0 to 3, marketing pitch content was only added (never subtracted), so the marketing pitches were "nested" in the same way that the product offers were.

${ }^{11}$ These impacts are large in economic magnitude. For example, Treatment 3 leads to an increase of \$285 in average account balances (across all accounts at the partner bank) in the 12 months post-treatment. By comparison, average balances at the partner bank were just \$183 in the comparison group (Treatment 0) over the same period.
} 
significantly different from zero. This result is also important, as it reveals that the frequentlymade policy recommendation to foster savings in migrants' home countries by encouraging migrants to remit directly into savings accounts of remittance recipients would be much less effective, compared to interventions that also improved and encouraged migrant monitoring and control over home-country savings.

We also provide additional evidence suggestive that the increases in savings due to Treatment 3 are due to improvements in migrant ability to control recipient savings in El Salvador. We show that savings increases in joint accounts at the partner bank (shared by migrants and someone in El Salvador) are concentrated among migrants who revealed a demand for control over remittance uses in the baseline (pre-treatment) survey (for example, among migrants who had previously sent funds to El Salvador for others to administer, or who were aware of disagreements between migrants and recipients over the use of remittances).

In addition, although both Treatments 2 and 3 offered joint accounts shared by migrants and someone in El Salvador, take-up of these accounts was statistically significantly higher in Treatment 3, when migrant-only accounts were also offered. This pattern is suggestive of decoy effects (Laran et al 2011, Chatterjee and Rose 2012). Offering migrant-only accounts as part of the menu of products may have drawn attention to the control features of accounts offered. The joint account, while not allowing the same degree of full control as the migrant-only account, provided greater control than most accounts that migrants remit into: it provided the migrant the opportunity to check balances and an ATM card with which to withdraw from the account. Offering the migrant-only account alongside the joint account in Treatment 3 may have encouraged migrants to pay more attention to the control features of the joint account.

We also provide evidence suggesting that our treatment effects do not derive from the marketing pitches alone. Joint account savings at other banks (aside from our partner bank) are not affected by the treatments. We interpret this as evidence that our offer of accounts at our partner bank were necessary to produce the effects on savings we observe.

The remainder of this paper is organized as follows. Section 2 provides details on the study design. Section 3 describes the characteristics of the sample. Section 4 presents the main empirical results. Section 5 provides discussion and additional analyses. Section 6 concludes.

\section{Study Design}

\section{Sampling Protocol and Baseline Survey}


Study participants are immigrants in the greater Washington D.C. area. To be eligible for inclusion in the sample, individuals had to have: 1) been born in El Salvador, 2) entered the U.S. for the first time within the last 15 years, and 3) sent a remittance to someone in El Salvador within the last 12 months.

Migrants were recruited as follows. We stationed our survey team at the two Salvadoran consulates in the Washington DC area (in DC and in Woodbridge, Virginia). The main services sought by study participants at the consulate were passport renewals, civil registration (of births, deaths, and marriages), and assistance with processing of Temporary Protected Status (a special provision allowing temporary legal work for Salvadorans and other nationalities who entered the U.S. after natural disasters or civil strife in the home country). The consulate of El Salvador serves Salvadorans regardless of their legal status, and so the sample likely includes both documented and undocumented migrants (we intentionally did not ask any questions related to immigration status.) The El Salvador consulate endorsed our study; intermittently, a consular staffer would make an announcement in the waiting area endorsing participation in the study.

Survey team members were mostly of Salvadoran origin, and mostly female. Survey team members approached individuals in the waiting area of the consulate, inviting them to participate in the study. The DC baseline survey fieldwork ran from June 2007 to January 2008. Individuals were told the name of the study, the academic institutions involved, and that the survey was about "Salvadorans who send remittances and their family who receive them in El Salvador." Individuals were asked the three screening questions (above), and if eligible were invited to participate. Those who agreed and signed consent forms were administered the baseline survey at the consulate. Of 5,288 people approached at the consulate, 3,611 passed the screening questions, and 1,986 agreed to participate and completed the baseline survey.

After completion of a migrant baseline survey in the DC area, a separate survey team attempted to survey the individual in El Salvador whom the migrant identified as his or her primary remittance recipient (or “PRR”). The survey team successfully completed 1,338 El Salvador household surveys between November 2007 and June 2008. After attempting a survey of an El Salvador household (whether successfully completed or not), a project staff member (a “marketer”) in DC then attempted to schedule (by phone) and carry out (in person) a marketing visit with the corresponding migrant, at which the treatments were administered. Many migrants were reluctant to make time for these visits, and we were unable to re-contact some respondents 
due to invalid or changed phone numbers. Marketers made appointments for 1,054 marketing visits. (Due to no-shows at the scheduled visits, our final sample size is slightly lower.)

Marketers carried out marketing visits at locations chosen by migrants. Random assignment to Treatment 0,1 , 2, or 3 occurred only after a marketing visit with the migrant had been scheduled, but before the actual visit was carried out. Study participants did not learn their treatment assignment prior to the actual face-to-face marketing visit. Visits took from 1-2 hours. Marketers were paid a flat fee for each completed visit that was the same for all treatment conditions (to avoid any differential incentive to complete visits of different types). The marketing visits were carried out between December 2007 and July 2008. The four treatments are described below, and details of marketing scripts are in Online Appendix A.

Our sample for analysis in this paper is 898 migrants with whom a face-to-face marketing visit was successfully carried out (along with their associated primary-remittance-recipient household in El Salvador). While attrition from the baseline survey to completed marketing visits is certainly detrimental to our sample size, it should not affect the internal validity of the study, because at no stage prior to the in-person marketing visit did study participants know their treatment assignment.

The resulting migrant sample comprises a reasonable cross-section of Salvadoran migrants in the Washington, D.C. area. Online Appendix Table 1 presents means of several key baseline variables for observations in our baseline data (column 1), in comparison with corresponding means for Salvadoran-born and Hispanic individuals in the US Census 2000 in the Washington DC metro area, separately for males and females. While differences are not dramatic, there are some key differences between our sample and US Census Salvadorans in the DC metro area. Focus for the moment on the comparison with column 2, for all Salvadoran-born individuals regardless of US citizenship. Our sample is more male, at 71\% vs. 57\%. Our sample has also arrived somewhat more recently in the US, with $49 \%$ and $51 \%$ of males and females, respectively, having been in the US for 5 years or less at the time of survey, compared to corresponding figures of 33\% and 29\% for US Census Salvadorans. Our sample is slightly more educated: $30 \%$ and $36 \%$ of our sample males and females, respectively, have a high school degree or more, compared to $27 \%$ and $30 \%$ of US Census Salvadoran males and females, respectively. Our sample is less likely to have US citizenship, at 0-1\%, compared to $10-12 \%$ for US Census Salvadorans. Finally, our sample is more likely to be married or partnered, at 53\% 
and $73 \%$ of males and females respectively, compared to $45 \%$ and $57 \%$ for male and female US Census Salvadorans, respectively. These differences vis-à-vis our baseline sample are quite similar when restricting the sample of US Census Salvadorans to those without US citizenship (column 3), and when examining Hispanics without US citizenship (column 4).

\section{Experimental Design}

In conjunction with our partner bank in El Salvador, Banco Agricola, we designed the savings facilities offered in this project, “Cuenta Unidos” and “Ahorro Directo” (described further below). Neither of these savings products existed previously. Our study only offered the new products to study participants randomized into certain treatment conditions. That said, anyone asking for these new products (say, if they heard about them from study participants) were allowed to open them by partner bank staff. To reduce contamination of our treatment effect estimates from spillovers to the comparison group (Treatment 0), our partner bank agreed not to market or advertise the new products designed for this study in any fashion until the follow-up survey was implemented (roughly a year after treatment).

Migrants were randomly assigned to one of three treatment groups or a comparison group, each with equal (25\%) probability. We randomized after stratifying migrants into 48 cells representing unique combinations four baseline categorical variables: gender (male, female), US bank account ownership (yes, no), primary remittance recipient’s relationship to migrant (parent, spouse, child, other), and years in US category (0-5, 6-10, 11-15). Stratified randomization was carried out between the completion of the baseline survey and the marketing visit attempt; because not all marketing visits were successful, it is not guaranteed that treatment conditions are precisely balanced on the stratification variables.

Treatments were administered in the marketing visits mentioned above. Migrants in the comparison group (labeled Treatment 0) were not offered any new products. (Because this study investigates control over savings, to avoid confusion we refer to Treatment 0 as the "comparison group”, not the “control group.”) The three treatment groups were labeled 1, 2, and 3. The presence of the comparison group allows us to observe outcomes for a comparable sample where none of the products were offered.

To help track migrants’ remittance behavior after the visit, all visited migrants were given a special card (called a "VIP card”) that provided a discount for sending remittances via Banagricola remittance locations in the DC area. Banco Agricola’s normal remittance charge is 
$\$ 10$ for a remittance up to $\$ 1,500$, and the VIP card allowed the migrant to send a remittance for a randomly-determined price of either $\$ 4, \$ 5, \$ 6, \$ 7, \$ 8$, or $\$ 9$ (once randomly assigned at the outset, the price was fixed for the validity period of the card). ${ }^{12}$ Eligibility for the card was conditional on the migrant presenting an identification document of some sort (usually a Salvadoran passport). Migrants were told to bring an identification document in the initial phone call making the appointment for the marketing visit.

\section{Treatment Groups}

Treatment 0 (comparison group): Encouragement to remit into bank account of someone in El Salvador

Migrants assigned to Treatment 0 were visited by a marketer who encouraged them to remit into El Salvador bank accounts. Marketers emphasized the benefits of remitting funds directly into accounts and of remittance-recipient access to funds via ATM/debit cards (rather than having to wait in a teller line to receive a remittance). Migrants were offered the VIP card, but were not offered any new savings facilities.

This generic pitch to remit into bank accounts was included in the control condition to ensure that any increases in savings seen in Treatments 1, 2, or 3 (vs. corresponding changes in Treatment 0 ) was not due simply to the encouragement provided by the marketers to remit into bank accounts in El Salvador.

Treatment 1: Offer of account for someone in El Salvador

In Treatment 1, marketers also emphasized the same benefits of remitting into bank accounts (as in Treatment 0), and provided the VIP card. But unlike in Treatment 0, in Treatment 1 this was combined with an offer of assistance in setting up an account in the name of someone in El Salvador, into which the migrant could remit. While the migrant would be able to make deposits into this account, the migrant would not be able to observe the balance of and withdrawals from this account. Relative to Treatment 0 , the Treatment 1 marketing pitch also added a brief comment that "savings for your remittance recipient in El Salvador" was a benefit of the Treatment 1 offer (but with no other elaboration on the general benefits of bank accounts). To equalize account-opening costs across Treatments 1 and 2, this remittance-recipient-only

\footnotetext{
${ }^{12}$ This remittance price randomization was independent of the randomization into Treatments $0,1,2$, or 3 , and so does not confound interpretation of any differences across treatments. In addition, migrants did not learn the actual discounted VIP price until after the marketing visit had concluded. The remittance price randomization was implemented for a separate study within the same study population on the impact of remittance prices on the frequency and amount of remittances (Aycinena, Martinez, and Yang 2010).
} 
account offered in Treatment 1 was exactly the same product (Cuenta Unidos) offered in Treatment 2. The difference was that in Treatment 1 we did not facilitate making the migrant a joint account-holder on the Cuenta Unidos account.

Migrants could identify anyone in El Salvador as the account holder (not just the “primary remittance recipient” or PRR to whom the baseline survey was administered.) If migrants were interested, they filled out forms to provide the name, address, and phone number of the individual in El Salvador for whom the account was intended. The marketer offered to let the migrant use a project cell phone to call the person in El Salvador during the visit to inform them of the new account. ${ }^{13}$ Within the next few days, project staff arranged by phone for the individual in El Salvador to meet with the branch manager of the nearest Banco Agricola branch in El Salvador to complete the final account-opening procedures in person.

Effects of Treatment 1 on take-up and savings accumulation (vis-à-vis Treatment 0) would reflect the impact of offering assistance with account-opening procedures. In addition, relative to Treatment 0 , Treatment 1 potentially improves what one might call the "identity precision” of remittances and savings: the migrant's ability to channel remittances towards a particular person's savings account. Because the account offered in Treatment 1 is in the name of someone in El Salvador, any impacts found could not be due to changes in the migrant's ability to monitor or control savings balances. Even if it failed to offer migrants greater monitoring or control, migrants might have found the account offered in Treatment 1 attractive if they thought that a savings account would be beneficial for the recipient, or if they wanted to use a recipient's savings account as a safe and convenient destination for remittances to that recipient.

\section{Treatment 2: Offer of joint account for migrant and someone in El Salvador}

In Treatment 2, we offered migrants the "Cuenta Unidos” account which was newly designed for this project. This savings facility allows joint ownership by both an individual in El Salvador and the migrant in the US. Joint account owners in both the US and El Salvador had ATM cards and full access to account information. Migrants could deposit funds into the account via remittances, withdraw with their ATM card via US ATMs, and check the balance on the account by calling a toll-free U.S. telephone number. Joint account owners in El Salvador could deposit and withdraw using their ATM cards or via bank tellers.

\footnotetext{
${ }^{13}$ To mitigate any possibility that talking to the primary recipient might have an effect on outcomes of interest, migrants assigned to Treatment 0 were also offered a complimentary phone call to the primary recipient from the project cell phone.
} 
The substantive content conveyed by the marketing pitch in Treatment 1 was also conveyed in Treatment 2, but in addition, the Treatment 2 marketing pitch also noted that both the migrant and the El Salvador account holder could verify the balance on the Cuenta Unidos account, and that the migrant could withdraw funds from the account from the US.

If migrants were interested in Cuenta Unidos, they filled out account-opening forms. As in Treatment 1, migrants provided contact information for the joint account holder in El Salvador, and marketers and other project staff facilitated the account opening process on the El Salvador side (by offering the migrant a free call on their project cell phone and arranging the account opening appointment in El Salvador). Migrants could identify anyone in El Salvador as the joint account holder. Migrants had the option to not have joint ownership of the new account (in other words, they could replicate the account offered in Treatment 1 ). ${ }^{14}$ Compared to Treatment 1, Treatment 2 offered migrants the ability to monitor the savings of family members, but did not provide full control over the funds. The joint account holder in El Salvador had complete freedom to withdraw the entire savings balance from the account.

Treatment 3: Offer of joint account for migrant and someone in El Salvador, plus migrant-only account

Treatment 3 nests Treatment 2, while adding an additional savings facility: an account exclusively in the migrant's name, known as “Ahorro Directo” (also newly designed for the project). This is an account only in the name of the migrant. The migrant could deposit into the account by remitting into it, and received an ATM card for withdrawals at US ATMs. ${ }^{15}$

In this marketing visit, Cuenta Unidos and Ahorro Directo were offered to the migrant in sequence. Cuenta Unidos was offered first, using a marketing script identical to the one used for Treatment 2. The marketing script for Ahorro Directo, which followed, emphasized its usefulness for exclusive control over funds, since the account would not be shared with anyone else. The script noted that no one other than the client would be able to check account balances, have access to the account, or even know of the existence of the account. The script also noted that no intermediaries (e.g., family members) would be needed for the client to save in El

\footnotetext{
${ }^{14}$ However, all accounts we assisted in opening in Treatment 2 were joint accounts. Not once did a migrant request to forego joint ownership of Cuenta Unidos in Treatment 2.

${ }^{15}$ A question that arises is why migrants would not have opened their own bank accounts in El Salvador prior to being offered them by our project. Our results will indeed show that the marketing and account-opening assistance offered by our project led to opening of these accounts. While our study is not designed to shed light on these barriers directly, it is likely that the reduction in transaction costs of account opening due to our account-opening assistance was non-trivial.
} 
Salvador. In addition, the script noted the benefit of improved security if visiting El Salvador by reducing the need to carry large amounts of cash. ${ }^{16}$

For the purpose of the study, it is important to be able to rule out that any differences across Treatments 2 and 3 are due to differences in transaction costs. Therefore, in Treatment 3 , if migrants wanted to open an Ahorro Directo account, we required them to also open a Cuenta Unidos account, ensuring that account opening transaction costs were identical across Treatments 2 and $3 .{ }^{17}$ In addition, migrants were allowed to open an account only in the name of a beneficiary in El Salvador (as in Treatment 1 ) if they requested it. ${ }^{18}$

In sum, Treatment 3 offered the migrant the greatest ability to control funds in savings accounts in El Salvador, unlike Treatment 2 where ownership had to be joint with someone else. The difference in takeup and savings between Treatments 2 and 3 therefore reveals the incremental impact of offering migrants the ability to exclusively control their El Salvador savings balances.

\section{Other important notes on the treatment conditions}

It is important to be clear that the pitch for each product did not vary across treatment conditions. However, because treatments differed in the products offered, treatments did involve different pitches that were delivered alongside their associated products. In particular, the joint account, Cuenta Unidos, was offered in both Treatments 2 and 3, but the pitch that accompanied that product offer was identical across those two treatments. In Treatment 3, Ahorro Directo was also offered, with its own additional pitch. Online Appendix A provides details on these productspecific pitches.

\footnotetext{
${ }^{16}$ Notwithstanding the way Ahorro Directo was marketed, one might imagine that migrants could still have used these accounts for joint savings with El Salvador persons, for example if migrants sent their Ahorro Directo ATM cards to individuals in El Salvador to provide them account access. There is no evidence that this occurred, however. Analysis of withdrawal data from these accounts shows that transactions on these accounts (both deposits and withdrawals) occurred exclusively on the US side over the period analyzed in this paper. Not a single deposit into or withdrawal from an Ahorro Directo account occurred in El Salvador through the end of 2009.

${ }^{17}$ By requiring that migrants wanting an Ahorro Directo also open a Cuenta Unidos, the migrant had to get an individual in El Salvador to physically visit a Banco Agricola branch there to fill out account-opening documents. If we had not instituted this requirement, then the transaction cost for opening an Ahorro Directo would have been much lower than for opening a Cuenta Unidos, because the former would not have required a trip by someone in El Salvador to a Banco Agricola branch. The upshot of this design is that take-up of Ahorro Directo in Treatment 3 will be a lower bound of what take-up would have been had we not instituted this requirement. We judged that improving clarity of interpretation was worth the sacrifice of potentially lower take-up in Treatment 3 . Note that in Treatment 1, the individual in whose name the account was opened also had to go to a branch in El Salvador, so transaction costs are also equalized with Treatment 1.

${ }^{18}$ Again, as in Treatment 2, no migrant assigned to Treatment 3 who chose to open a Cuenta Unidos account opted to forego joint ownership.
} 


\section{Outcome variables}

The primary outcome variables we examine are savings balances of various types at the partner bank, which we obtained from the partner bank's administrative databases. We focus on savings balances over the 12 post-treatment months (after the study participant's marketing visit), but we also provide estimates of treatment effects up to 48 months post-treatment. To obtain these data, both the migrant and his or her primary remittance recipient (PRR) were located in the partner bank's administrative data via a search on the basis of matching variables (given name, surname, address, phone number, and age) that were obtained from study participants before treatment assignment. The search was performed by bank staff on the basis our instructions. We provided bank staff with the matching variables, to ensure that no additional identifying data (such as improved addresses and phone numbers) that might have been obtained from individuals taking up products in the treatment groups would be used in the matching process. Had we not done so, our treatment effects on bank balances would be biased upwards because more individuals might have been successfully found in the treatment groups that involved take-up of bank products. ${ }^{19}$

It should be noted that this matching procedure locates only accounts owned by either the migrant or PRR (or both). In other words, it locates joint accounts shared by migrants and PRRs, joint accounts shared by migrants and individuals other than the PRR, accounts held only by the PRR (without migrant co-ownership), and accounts held only by the migrant (without PRR coownership). However, the procedure fails to locate accounts that migrants might have opened in the name of non-PRRs alone (without migrant co-ownership), because we do not have a pretreatment list of potential non-PRR account holders to search for in the database. To the extent that migrants did open accounts in the name of non-PRRs alone, our results here will understate the impacts of the interventions on account-opening and savings.

In addition, we fielded migrant follow-up surveys roughly one year after the initial product offer (from March to June 2009) to measure impacts on savings outside of the partner bank. Follow-up surveys of DC-based migrants were conducted via phone by a survey team calling from El Salvador.

\section{Estimation strategy}

\footnotetext{
${ }^{19}$ We have confirmed that the data quality of the matching variables are not differential by treatment status. Further confirmation that the quality of the matching did not vary by treatment status is that prior to treatment, savings balances at the partner bank are balanced across treatment conditions (see Appendix Table 2).
} 
Dependent variables of interest in this paper are take-up rates of and balances in savings accounts at the partner bank. Let $\mathrm{Y}_{\mathrm{i}}$ be the dependent variable of interest (say, total savings at the partner bank). Let $\mathrm{Z}_{\mathrm{i}}$ be an indicator variable for assignment to Treatment $1, \mathrm{Z}_{\mathrm{i}}$ be an indicator variable for assignment to Treatment 2 , and $\mathrm{Z3}_{\mathrm{i}}$ be an indicator variable for assignment to Treatment 3. We estimate treatment effects using the following regression equation:

$$
\mathrm{Y}_{\mathrm{i}}=\delta+\alpha_{1} \mathrm{Z1}_{\mathrm{i}}+\alpha_{2} \mathrm{Z}_{\mathrm{i}}+\alpha_{3} \mathrm{Z}_{\mathrm{i}}+\boldsymbol{X}_{\boldsymbol{i}} \boldsymbol{\phi}+\mu_{\mathrm{i}}
$$

Coefficients $\alpha_{1}, \alpha_{2}$, and $\alpha_{3}$ are the impact on the dependent variable of Treatments 1,2 , and 3, respectively. We focus on intent to treat (ITT) effects, and so are estimating the effect of offering (rather than opening) the various accounts.

The difference $\left(\alpha_{3}-\alpha_{2}\right)$ represents the difference in the impact of Treatment 3 vis-à-vis Treatment 2, and the difference $\left(\alpha_{2}-\alpha_{1}\right)$ represents the difference in the impact of Treatment 2 vis-à-vis Treatment $1 . \boldsymbol{X}_{\boldsymbol{i}}$ is a vector of control variables which include fixed effects (for marketer, stratification cell, and month of marketing visit when treatments were administered) and an indicator variable for the individual expressing demand for control over financial decision-making of primary remittance recipients in the baseline survey (described further below). $\mu_{\mathrm{i}}$ is a mean-zero error term. For all coefficient estimates, we report robust (Huber/White) standard errors that account for survey design. ${ }^{20}$

One of our key dependent variables is savings balances, which potentially have large outliers that could have disproportionate influence on the estimates. Therefore, in all results tables for impacts on savings balances, we focus on impacts on the quartic root of savings balances, a specification which reduces the influence of outliers (these will be presented in Panel A of the relevant tables). We also report impacts on the dollar amount of savings balances (in Panel B), but will consider this specification secondary to the quartic root specification.

\section{Sample Characteristics}

Our primary sample for analysis, which we use to analyze impacts on savings at the partner bank, consists of the 898 DC-area migrants who completed a baseline survey as well as a marketing visit some months later.

\section{Characteristics of migrants and remittance-receiving households}

\footnotetext{
${ }^{20}$ Specifically, regressions are run with Stata’s “svy” option, where data are "svyset” to account for survey strata (the stratification cells).
} 
Summary statistics are presented in Table 1 . Several measures of demand for control are available in the baseline survey administered to migrants. We construct five separate indicator variables equal to one (and zero otherwise) from migrant reports of the following: a) the migrant had ever paid directly for expenditures of remittance recipients in El Salvador, rather than sending cash (7.7\% of migrants did so); b) the migrant had sent funds home for others to administer on his/her behalf (23.7\% of migrants did so); c) the migrant was interested in direct payments to improve control over remittance uses (20.7\% of migrants said yes); d) the migrant knew anyone who had had conflict with recipients over remittance uses (14.6\% of migrants said yes); e) the migrant has had conflict with his/her own remittance recipients over remittance uses (4.9\% of migrants said yes). We construct an overall indicator of "demand for control" that takes on the value of 1 if the migrant answers affirmatively to any of the five abovementioned indicator variables, and 0 otherwise. 51\% of migrants answered "yes" to at least one of these questions.

The baseline survey also included three questions assessing financial literacy that have been included in surveys of financial literacy worldwide (Lusardi and Mitchell 2006). ${ }^{21} 66 \%$, $64 \%$, and $37 \%$ of migrants responded correctly to the questions on (respectively) compound interest, inflation, and mutual funds. We also asked whether migrants tracked spending and budgeted expenses. $46 \%$ of migrants reported "always" or "almost always" doing so.

\section{Balance and attrition across treatment groups}

It is important to check whether randomization across treatments achieved the goal of balance in terms of pre-treatment characteristics of study participants. Online Appendix Table 2 presents the means of a number of baseline variables for each treatment group as reported prior to treatment. The first column of reported p-values is for F-tests of equality of means across the treatment groups, for each variable separately. The other three columns of p-values are for Ftests of the pairwise equality of means between observations in Treatment 0 and (respectively) Treatments 1, 2, and 3. The table also examines account ownership and average savings balances

\footnotetext{
${ }^{21}$ The questions are: 1) "Suppose that you have $\$ 100$ in a savings account with a $2 \%$ annual interest rate. If you do not touch the money in this account, how much do you think you will have in five years?" (Options are "less than \$102”, "exactly \$102", and “more than \$102”; correct answer is “more than \$102”.); 2) "Imagine that the interest rate in the savings account where you have $\$ 100$ is $1 \%$, and that inflation is $2 \%$ per year. A year from now, would you be able to buy more, the same, or less than today with the money in the account?" (correct answer is "buy less"); and 3) "Do you think that the following statement is true or false? To buy stocks in only one company is more secure than to invest in a mutual fund" (correct answer is "false").
} 
of study participants at the partner bank, during 12 months prior to the month of the marketing visit (specified as the quartic root and in dollars, in parallel to the regression results to come).

The first 9 variables listed in the table are the stratification variables (gender, US bank account, relationship to remittance recipient, and years in US category). The p-values on the Ftest of the joint equality of means across all treatments are all far from conventional significance levels. In only one out of 27 pairwise comparisons with the Treatment 0 mean is there a statistically significant difference in means (the comparison between Treatments 2 and 0 for “recipient is migrant's other relative”). ${ }^{22}$ This one rejection of equality is not worrisome, however, as the regression estimates to come will control for stratification cell fixed effects (estimates will take advantage only of variation in treatment within stratification cell), and all results are robust to inclusion or exclusion of the stratification cell fixed effects.

The remaining variables in the table are other variables for which observations were not stratified prior to treatment assignment. For all these remaining variables, the p-values in essentially all cases are also large and we cannot reject the hypothesis that the means are identical across treatment groups. ${ }^{23}$

Follow-up attrition rates across treatments are presented in the bottom row of Online Appendix Table 2. ${ }^{24}$ The follow-up survey contains 508 observations with valid migrant-reported savings data, for an overall attrition rate of 43.4\%. Attrition rates between Treatment 1 and Treatment 0 are not statistically significantly different from one another (45\% and 49\% respectively). However, observations in Treatment 2 have statistically significantly lower attrition rates than Treatment 0 (amounting to 10 percentage points lower attrition). In addition, Treatment 3 has about 7 percentage points lower attrition than does Treatment 0 (and this difference is marginally statistically significant, with a p-value of 0.13 ).

This pattern of treatment-related attrition raises concerns about selection bias in estimates of treatment effects on outcomes measured in the follow-up survey. In Online Appendix Table 3,

\footnotetext{
${ }^{22}$ As mentioned earlier, stratification was carried out prior to the marketing visit, and so failure to complete the marketing visit could have led to imbalance on the stratification variables. In addition, some of the stratification cells had small numbers of migrants. When the number of migrants in a cell was not a multiple of 4 , it was not possible to assign exactly $25 \%$ of migrants within cell to each treatment.

${ }^{23}$ The three exceptions are the pairwise comparison between Treatments 2 and 0 for "migrant's annual remittances sent", "migrant is US citizen", and "migrant is married or partnered", in which cases the means are significantly different at the $10 \%$ level. This small number of significant differences can be expected to arise by chance even with randomization.

${ }^{24}$ Attrition can be due to non-completion of the follow-up survey as well as missing savings data in that survey.
} 
we investigate balance of baseline characteristics across treatment conditions in the follow-up sample ( $\mathrm{N}=508$ ), analogous to those examined in Online Appendix Table 2. While across most variables there does not seem to be dramatic evidence of differences across treatment conditions in the follow-up sample, there does seem to be worrying imbalance in pre-treatment savings at the partner bank. An F-test rejects equality of the quartic root of savings at the partner bank prior to treatment across all treatment groups at the $10 \%$ level, and the difference in this variable between Treatments 3 and 0 is statistically significant at the $5 \%$ level. ${ }^{25}$

Due to these patterns of differential survey attrition and imbalance in the follow-up survey sample, care must be taken in interpretation of any treatment effects estimated using this sample. Our focus, therefore, will be on the outcomes observed in the administrative data from the partner bank, which are not subject to such concerns. ${ }^{26}$

\section{Impact of Treatments on Savings}

In this section we examine the impact of the treatments. We first discuss impacts on account opening and on savings in accounts at the partner bank. We then discuss whether treatment effects are likely to reflect shifting of funds across savings mechanisms, and in that context examine treatment effects on savings reported in the follow-up survey.

\section{Impact on account opening at partner bank}

We first estimate equation (1) examining the impact of the various treatment conditions on take-up of savings accounts at the partner bank. We regress an indicator for the existence of a certain type of account in the first through $12^{\text {th }}$ month post-treatment on indicators for being assigned to each of treatment conditions 1 through $3 .{ }^{27}$ We examine three categories of accounts separately, distinguishing between the two types of new accounts designed for this research project ("project accounts") and other accounts at the partner bank:

1) Cuenta Unidos accounts. Recall that in Treatments 2 and 3, we offered Cuenta Unidos accounts as joint accounts between migrants and someone in El Salvador. In Treatment 1,

\footnotetext{
${ }^{25}$ It is also the case that, among observations assigned to Treatments 2 and 3, attrition from the follow-up survey is statistically significantly lower for those with higher post-treatment savings at the partner bank (as observed in the partner bank's internal data).

${ }^{26}$ We also implemented follow-up surveys of households of the primary remittance recipient in El Salvador. This survey suffered from even higher attrition, and similar problems with baseline imbalance in partner bank savings. We do not present here treatment impacts on outcomes measured in these El Salvador household surveys. That said, impacts on savings in this sample are consistent with those found in the migrant follow-up sample.

${ }^{27}$ The indicator is equal to 1 if such an account exists at any time during months 1-12 post-treatment (including accounts that may have been open for only part of this period), and 0 otherwise.
} 
the accounts we offered were also Cuenta Unidos accounts, but in that case we did not offer migrants the opportunity to be joint account holders - the accounts were offered as accounts for individuals in El Salvador alone. ${ }^{28}$

2) Ahorro Directo accounts. These accounts were in the name of migrants only.

3) Other accounts in the name of the migrant or the PRR, excluding those (Cuenta Unidos and Ahorro Directo) offered by our project. ${ }^{29}$

Coefficient estimates for regression equation (1) where the dependent variable is existence of a Cuenta Unidos account are regressions labeled (a) in Table 2 (without and with, control variables, respectively). The coefficient on the constant term in the first column of (a) indicates that for $5.9 \%$ of migrant-PRR pairs assigned to the comparison group (Treatment 0 ), a Cuenta Unidos account existed during the 12 months post-treatment. (Individuals in Treatment 0 could have obtained one of these accounts if they learned about their existence independently of our marketing team, and could have obtained the account opening documents by calling the partner bank's toll-free number in the US.)

The coefficients in the first column of (a) on Treatments 1, 2, and 3 are all positive in sign, and are each statistically significantly different from zero at the $1 \%$ level. The coefficients indicate that Treatments 1, 2, and 3 led, respectively, to 15.0, 14.1, and 22.1 percentage points higher likelihood of owning a Cuenta Unidos account. These coefficients are very similar when control variables included in the regression.

Regressions (b) of the table are similar, except that the dependent variable is an indicator for the existence of an Ahorro Directo (migrant-only) account. The constant term in the first column of (b) indicates that $4.1 \%$ of migrants in the comparison group opened such accounts (independently of the assistance of our project). The proportion is similar among migrants in Treatments 1 and 2: the coefficients on the indicators for those treatments are small and not

\footnotetext{
${ }^{28}$ Due to restrictions on how the partner bank was willing to share data with us, we cannot actually differentiate in the partner bank administrative data between Cuenta Unidos accounts held by both migrants and someone in El Salvador, and Cuenta Unidos accounts held by only someone in El Salvador (without migrant co-ownership). However, we know from our project marketing records that in Treatments 2 and 3, not a single migrant who opened an account for someone in El Salvador in Treatments 2 or 3 opted to forego joint ownership of the account. In Treatment 1, all accounts opened with the assistance of our project staff were in the name of a person in El Salvador alone (consistent with instructions for that treatment). In all treatments, migrants could have found other ways of opening Cuenta Unidos accounts without our assistance, and if they did so the accounts would be either joint accounts with the migrant or accounts in the name of an El Salvador person alone.

${ }^{29}$ These "other" accounts would have already existed prior to treatment or, if new, would have been opened without the assistance of our project staff.
} 
statistically different from zero. The coefficient on Treatment 3, on the other hand, is large and statistically significant at the $1 \%$ level, indicating that migrants in that treatment condition were 23 to 24 percentage points more likely to open an Ahorro Directo account than those in the comparison group.

Finally, regressions (c) replace the dependent variable with an indicator for the migrant owning some other account at the partner bank. The coefficient on the constant in the first column of (c) indicates that in 26.5 percent of migrant-PRR pairs, either migrant or PRR has some other account at the partner bank. It appears that none of the treatments led to increased ownership of these other accounts: there is no large or statistically significant effect of any of the treatments on this outcome variable in either regression for this dependent variable.

The bottom rows of the table present p-values of F-tests of the difference between pairs of treatment coefficients. For opening of Cuenta Unidos accounts, the impact of Treatment 3 is statistically significantly different from the impact of Treatment 2 at the $5 \%$ level, and is statistically significantly different from the impact of Treatment 1 at the $10 \%$ level. This pattern is also exhibited (at 1\% significance levels) in regressions (b) (for opening of Ahorro Directo accounts). The impact of Treatment 2 is not statistically significantly different from the impact of Treatment 1 at conventional significance levels in any of the regressions in the table.

\section{Impact on savings at the partner bank}

We estimate equation (1) to examine the impact of the treatments on savings balances at the partner bank. In Table 3, the dependent variables are average savings balances over the 12 months after treatment for the various categories of accounts. Regressions where dependent variables are expressed as the quartic root of savings are presented in Panel A of each table, with corresponding results for savings in dollars in Panel B.

In the first two columns of Table 3, the dependent variable is savings in Cuenta Unidos accounts. $^{30}$ The first column reports coefficient estimates for regressions without control variables, while the second column provides corresponding estimates but where control variables are included in the regression (this format is repeated for other dependent variables in subsequent

\footnotetext{
${ }^{30}$ As mentioned above, due to the ambiguity in the partner bank's database, we cannot distinguish between Cuenta Unidos savings in joint accounts from Cuenta Unidos savings in accounts in the name of someone in El Salvador alone. However, due to the assistance we provided in account opening in Treatments 1 , 2, and 3, it is most likely that in Treatments 2 and 3 accounts opened via this project are joint accounts, while in Treatment 1 they are most likely not joint accounts. In Treatment 0 , the few observed Cuenta Unidos accounts were opened without our staff's assistance so we do not know whether these are joint accounts or not.
} 
columns). All treatments have positive impacts on Cuenta Unidos savings balances. Estimates in Panel A indicate that each treatment has a positive effect on the quartic root of savings, all at conventional levels of statistical significance. In Panel B, coefficient estimates of the impact on the dollar value of savings are also positive, but are mostly not statistically significantly different from zero at conventional levels.

Results in the $3^{\text {rd }}$ and $4^{\text {th }}$ columns of the table reveal positive impacts of Treatment 3 on savings in Ahorro Directo accounts. These effects are statistically significant at the $1 \%$ level for the quartic root of savings, and at the $10 \%$ level for savings in dollars. ${ }^{31}$

In the $5^{\text {th }}$ and $6^{\text {th }}$ columns, where the dependent variables refer to savings in other partner bank accounts, point estimates of the effects of Treatment 3 are large in magnitude, but with one exception (in the first regression in Panel B) they are not statistically significantly different from zero. Estimated effects of Treatments 2 and 1 are mostly small in magnitude, inconsistent in sign across specifications, and not statistically significantly different from zero.

In the last two columns of the table, dependent variables refer to total savings at the partner bank. Impacts of Treatment 3 are all large, positive, and statistically significantly different from zero (at the 1\% level in Panel A, and the 5\% level in Panel B). Point estimates of the effects of Treatments 2 and 1 are all also positive, but are all smaller in magnitude and are not statistically significantly different from zero. In Panel A, we can reject that the effect of Treatment 3 is equal to the effect of either Treatments 2 or 1 at conventional significance levels (5\% or better). In Panel B, the effect of Treatment 3 cannot be distinguished from that of Treatment 2 at conventional levels, but is statistically significantly larger than the effect of Treatment 1 at the $10 \%$ level.

The result in the last column (with control variables), Panel B, indicates that Treatment 3 led total savings at the partner bank to be larger by $\$ 282$. This is a large increase over mean partner bank savings in the comparison group (\$186).

To provide a sense of the percentiles of the savings distribution that are contributing to these treatment effects, Figure 1 presents the cumulative distribution function of the quartic root of total savings in all project accounts (the dependent variable of the last two columns of Table 3,

\footnotetext{
${ }^{31}$ Interestingly, coefficients are actually negative for Treatments 2 and 1 in these regressions. This may reflect the fact that marketing Treatments 2 and 1 focused on encouraging savings in accounts of remittance recipients, and did not encourage migrant-only accounts. However, we do not highlight these results, since these impacts are mostly not statistically significantly different from zero (and the statistically significant Treatment 2 coefficient in column 3 is not robust to inclusion of control variables).
} 
Panel A). The CDF is truncated on the vertical axis at the $50^{\text {th }}$ percentile to enhance visibility. ${ }^{32}$ The CDF for Treatment 3 is clearly shifted to the right compared to the CDFs of the other treatments. While treatment effects show up relatively high in the savings distribution, it is far from the case that the estimated impacts of Treatment 3 are driven solely by the very topmost percentiles of the savings distribution.

\section{Exploring shifting across savings mechanisms}

A question that naturally arises at this point is whether the treatments led to increases in savings overall, or whether increases in savings seen at the partner bank were simply shifted from other savings mechanisms (e.g., cash, or other banks). That said, even if all increases we find in partner bank savings were simply reallocations of existing savings held elsewhere, our results so far would still be revealing of migrant demand for control over home-country savings. Reallocation of savings across savings mechanisms is in itself a consequential financial behavior that individuals are not likely to take lightly.

The most natural type of savings reallocation to examine, which we turn to first, is shifting of funds from other partner bank accounts to the project accounts. This is an important type of shifting to examine, since if study participants do shift, it should be easiest to do so from type of one account to another within the partner bank. The results in Table 3 allow us to easily check for evidence of shifting of funds within the partner bank. A pattern that would be consistent with shifting would be negative coefficients on treatment coefficients in columns (c) where the dependent variable is savings in other (non-project) accounts. In addition, if such shifting was large enough, we could find no statistically significant impact on total savings at the partner bank (columns d).

It turns out that neither pattern emerges. Coefficients in both column (c) regressions are mostly positive (across Panels A and B), and when negative are small in magnitude and not statistically significantly different from zero. Indeed, the coefficients on Treatment 3 in column (c), in both Panels, are positive, large in magnitude, and hover around the threshold of statistical significance, indicating if anything a positive spillover towards “other” saving (rather than shifting). In addition, column (d) indicates that, overall, total savings at the partner bank did increase in response to Treatment 3 , an effect that is statistically significant at conventional

\footnotetext{
${ }^{32}$ Recall from Table 2 that at most (in Treatment 3), only 55\% of observations had any account at the partner bank, so it is expected that there are many zeros in the data. The percentage of observations with zero savings at the partner bank in Treatments 3, 2, 1, and 0 is, respectively, 55\%, 66\%, 64\%, and 68\%.
} 
levels in both Panels. The results in Table 3, in sum, provide no evidence that treatment effects are driven by shifting of funds within the partner bank.

Of course, shifting could also occur from funds held outside the partner bank. It is therefore also useful to examine impacts of the treatments on the stock of savings more broadly, as reported by respondents in the follow-up survey (administered roughly one year after the intervention). Negative impacts on certain types of savings would be revealing of shifting, while there is of course the possibility of positive spillovers on other types of savings, perhaps due to the marketing pitch delivered with the new account offers. ${ }^{33}$

Table 4 presents regression estimates of the impact of each treatment on savings reported by migrants (the dependent variables are expressed as the quartic root of savings in Panel A and in dollars in Panel B). The four columns present impacts on savings reported by the DC-based migrant, (a) in banks in El Salvador, (b) in banks in the U.S., (c) in cash, and (d) in total across the previous three categories. In both panels, effects of Treatment 3 are positive and large in magnitude for savings in El Salvador banks, in US banks, and in total, but most of these coefficients are not statistically significantly different from zero at conventional levels. The exception is the impact of Treatment 3 on the quartic root of savings in the U.S. (Panel A, column b) which is statistically significantly different from zero at the $10 \%$ level. It also appears that the treatment shifted savings away from cash: the Treatment 3 coefficient in column (c) is negative and significant at the 5\% level in both Panels A and B.

It appears that Treatment 3 had a positive and statistically significant impact on migrant savings in the US. We note that the point estimates of impacts of Treatment 3 on the dollar value of El Salvador bank savings and on total savings (Panel B of Table 4) are positive and larger in magnitude than the impacts on total savings at the partner bank (see Online Appendix Table 4). If the impacts on total savings at the partner bank were simply due to shifting of funds from other savings vehicles, then treatment effects in Table 4 should have been smaller in magnitude than those in Online Appendix Table 4. There is therefore no indication that the impacts on total savings at the partner bank are simply due to shifting from other savings vehicles.

\footnotetext{
33 The qualitative results of Table 3 (that were from regressions with the full 898-observation sample) carry through in the smaller $(\mathrm{N}=508)$ follow-up survey sample. Impacts of the treatments on partner bank savings in this subsample are presented in Online Appendix Table 4. The pattern of impacts on partner bank savings in the 12 months post-treatment (as well as statistical significance levels) in the smaller follow-up samples correspond to those in the full sample, and in many cases point estimates are even larger in magnitude.
} 
However, recall that (as discussed in Section 3 above) this follow-up sample suffers from differential attrition related to treatment, as well as imbalance in baseline pre-treatment savings at the partner bank across treatment conditions. These estimates from the follow-up survey data should therefore be interpreted with caution, as they may reflect selection bias. ${ }^{34}$

\section{$\underline{V}$. Discussion and Additional Analyses}

We now present additional analyses and discussion to help interpret our results, explore impacts beyond the first 12 months, and examine impacts on remittances.

\section{Heterogeneity in treatment effects by baseline demand for control}

A central motivation of this study is the hypothesis that the accounts offered to migrants (particularly those in Treatments 2 and 3) would lead to increased savings because they allowed migrants to exert greater control over savings in the home country. To test this interpretation of our results, we examine the extent to which our treatment effects are heterogeneous vis-à-vis the extent to which migrants, in the baseline survey, expressed demand for control over financial decision-making in El Salvador primary remittance recipient households.

Estimates of treatment effect heterogeneity are presented in Table 5. The regressions are analogous to those of Table 3 where the dependent variables are different types of savings at the partner bank, but now the treatment indicators are each interacted with an indicator for the migrant expressing demand for control at baseline (defined above in Section 3; 51\% of migrants have "demand for control"), and an indicator for "no demand for control" (simply one minus the demand for control indicator). The regressions include all control variables (including the main effect of the "demand for control" indicator). ${ }^{35}$

The coefficient on each interaction term is the effect of the given treatment on savings for migrants with or without baseline demand for control. F-tests (with p-values reported at the bottom of each panel) test the null that the treatment effect is the same across migrants with vs. without demand for control.

In column (a) of Panel A the dependent variable is the quartic root of savings in Cuenta Unidos accounts. The coefficient on Treatment $3 *$ (Demand for control) is positive and significant at the $1 \%$ level, while that on Treatment $3 *$ (No demand for control) is much smaller

\footnotetext{
${ }^{34}$ That said, including controls in the regression for baseline savings at the partner bank (the quartic root and in dollars) has essentially no effect on the treatment coefficient point estimates or standard errors in Table 4.

${ }^{35}$ Main effects for each treatment do not need to be included because they are fully interacted with "demand for control" and "no demand for control".
} 
in magnitude and is not significant at conventional levels. This pattern also holds for the Treatment 2 interaction terms. In both these cases, an F-test rejects (at the 5\% level) equality of the treatment effects across migrants with and without demand for control. In column (a) of Panel B, where the dependent variable is expressed in dollars, the qualitative pattern of results is the same, but significance levels are lower and F-tests cannot reject equality of coefficients across migrants with and without demand for control. This pattern of treatment effect heterogeneity for Treatments 3 and 2 is consistent with migrants exerting control over remittance-recipient savings in accounts jointly held by migrants and remittance recipients.

Interestingly, unlike in column (a), in column (b) (where the dependent variable is savings in migrant-only Ahorro Directo accounts) it is not the case that Treatment 3 has greater impact on savings among migrants with demand for control. In fact, the pattern is reversed: in both panels, only Treatment 3 * (No demand for control) is statistically significant at conventional levels, it is substantially larger in magnitude than the coefficient on Treatment 3 * (Demand for control). F-tests reject (at the 5\% level) the equality of the coefficients.

The contrasting results in columns (a) and (b) suggest that migrant desire to control savings decision-making is associated with the objectives behind savings in the home country, and therefore choice of savings product. Migrants with demand for control may desire savings to be used to primarily for objectives of the remittance recipient, and seek to exert control to help ensure the objectives are met. For example, migrants may seek control over savings to help El Salvador households build up buffer stocks (precautionary savings) that can be accessed quickly by the household in emergencies. This may be the reason behind the differentially large effect of Treatment 3 on joint account savings (columns a and b) for migrants with demand for control.

Migrants without demand for control, on the other hand, may be saving primarily to achieve their own objectives (objectives not shared with the remittance recipient). For these migrants, access to bank accounts by El Salvador individuals is immaterial, so they are not attracted to joint accounts. For example, such migrants may simply want to keep some savings in El Salvador for themselves, to provide easy access during visits home or as a safe place to keep funds in case the migrant is deported and faces difficulty accessing US bank accounts. These migrants therefore save only in the migrant-only accounts. This may explain the differentially large effect of Treatment 3 for migrants without demand for control in column (b). 
In columns (c) and (d), analogous results are presented for savings in other types of accounts (not offered by the project) and for total savings at the partner bank. In Panel A's results for the quartic root of these savings variables, while the coefficient on the Treatment 3 interaction term is larger for migrants with than without demand for control, we cannot reject at conventional levels that these coefficients are equal to one another. In Panel B, on the other hand (savings in dollars), the Treatment 3* (Demand for control) coefficient is larger than that on Treatment $3 *$ (No demand for control) at the $10 \%$ level in both columns.

\section{Decoy effects}

One pattern in the results is that the impacts related to the joint account (Cuenta Unidos) is higher in Treatment 3 than in Treatment 2. This pattern is most prominent in analysis of impacts on account opening in Table 2, regressions (a): the coefficient on Treatment 3 is larger than that on Treatment 2 (by about 8 percentage points), and the difference between the two is statistically significantly different from zero at the $5 \%$ level. The same qualitative pattern also arises for treatment effects on savings in joint accounts (first two columns of Table 3, Panel A): the coefficient on Treatment 3 is larger than the coefficient on Treatment 2, although differences are not statistically significant in this case.

This pattern is a bit of a puzzle for standard models of economic decision-making, since the Cuenta Unidos joint account was offered in both Treatment 3 and Treatment 2. One explanation for this result is that the offer of the migrant-only Ahorro Directo account in Treatment 3 had a "decoy effect" on demand for the joint account. ${ }^{36}$ Other research has documented decoy effects, or shifts in preference for a certain option when presented with another option that might be thought to be irrelevant. For example, Laran, Dalton and Andrade (2011) find that priming brands such as Walmart increases consumers' cost consciousness and subsequently reduces their spending intentions - even on alternative products. Chatterjee and Rose (2012) found that people primed with cash would then focus on the costs of products while those primed with credit cards would focus on the benefits. Then they introduced "decoy products": in the cash option they introduced a decoy for the benefits choice, while in the credit card option they introduced a decoy for the costs choice. This countered the initial priming, reducing the salience of the benefits choice for the credit card prime and of the cost choice for

\footnotetext{
${ }^{36}$ Recall that the "pitch" for the joint account was the same in both Treatments 2 and 3 . The difference between the treatments was that Treatment 3 also offered the Ahorro Directo migrant-only account, with its own separate pitch.
} 
the cash prime. In other words, the existence of an additional product with certain features functions exactly as priming through other sources does: it focuses the attention of the individual on those features in evaluating all the products.

In our study, migrants who were offered both the joint account and the migrant-only account (Treatment 3) were more likely to open the joint account than those who were offered only the joint account (Treatment 2). That is, the presence of a third option changed the migrants' valuation of the joint account. We believe this likely represents a decoy effect in the sense of the literature referenced above. A related concept in economics is a menu effect; both are violations of the independence of irrelevant alternatives axiom.

In our case, we think the effect of the option of a private savings account focused the migrants on the control features of the joint account, increasing their valuation of the joint account. Marketing of the migrant-only savings product emphasized the importance of control over savings. It is likely that this caused migrants to consider the control aspects of the joint account more so than when the joint account was offered in isolation. As in Laran et al (2011), where the addition of Walmart to a choice set primed subjects to weight cost more, offering the migrant-only account likely focused migrants on the control features of the joint account.

\section{Ruling out that effects are due to marketing pitch alone}

One question that arises is whether treatment effects are due to the marketing pitch alone, or whether it is crucial that the intervention offered the accounts and account-opening assistance at the partner bank. The concern is that the set of marketing pitches implemented might have been enough to encourage migrants to exert control over funds in joint accounts that already existed or that they could easily set up on their own. Then the intervention's offer of the joint accounts at the partner bank (and account-opening help) may have been superfluous.

To test this, we use the migrant follow-up survey data to check whether Treatment 3 led to increases in savings held jointly by migrants and El Salvador individuals at other (non-partner) banks. If the intervention's offer of assistance opening joint accounts at the partner bank was superfluous, and the marketing pitch was all that mattered, then we should also see Treatment 3 have positive effects on savings at other banks (many of whose branch locations may have been more conveniently located for family members in El Salvador).

Regression results are in Online Appendix Table 5. The dependent variables in the two columns are savings reported by the migrant in joint accounts outside the partner bank shared 
with primary remittance recipients (column 1) and with other people, not including the primary remittance recipient (column 2). Dependent variables are expressed as the quartic root in Panel A, and in dollars in Panel B. There is no indication that Treatment 3 affects savings in joint accounts with primary remittance recipients outside of the partner bank: Treatment 3 coefficients in columns 1 or 2 are statistically significantly different from zero. (Interestingly, there does seem to be an effect of Treatment 2 on joint savings with non-PRRs outside of the partner bank, which is positive and statistically significant at the $10 \%$ level.)

We conclude from this analysis that the marketing pitch alone cannot explain Treatment 3's impact on savings at the partner bank, and that it was crucial that the treatment offered actual bank accounts and assistance in opening them.

\section{Longer-term impacts}

Our results so far refer to savings roughly one year after treatment. Outcomes in administrative data are average savings balances over the 12 post-treatment months, while outcomes in the follow-up survey refer to savings stocks at a point in time about 12 months posttreatment. An important question is whether the effects of the treatment extended further in time. Because we did not administer further follow-up surveys, this analysis is limited to savings outcomes in the administrative data of our partner bank.

It is important to note that our agreement with the partner bank was that general marketing of the new products designed for the project (Cuenta Unidos and Ahorro Directo) would be restricted until administration of the follow-up survey. During this period, the new products were only offered by our project marketing staff on a face-to-face basis to study participants, and there was no marketing of these products to customers more generally. This was done to reduce the extent to which marketing spillovers across treatment and comparison groups would contaminate (and attenuate) our treatment effect estimates. After the follow-up survey, roughly one year after the treatments were administered, the partner bank did begin marketing the Cuenta Unidos and Ahorro Directo accounts broadly in both the U.S. and in El Salvador. Generalized take-up of the new products could therefore lead all treatment groups to become increasingly similar to one another in terms of product usage, preventing the data from revealing whether treatment effects persist over time.

This does turn out to be the case. In Table 6 we examine impacts of the treatments on total savings across accounts at the partner bank in 6-month windows up to 48 months post- 
treatment. (In all respects, the regressions are analogous to that of the last column of Table 3, except that average savings balances are measured over differing months post-treatment.) Results in the first two columns reflect results reported previously in Table 3: there are positive and statistically significant effects of Treatment 3 on total partner bank savings in months 1-6 and months 7-12 post-treatment, in both the quartic root and dollar specifications. The impact persists into months 13-18 post-treatment: the coefficient on Treatment 3 in the quartic specification remains positive and statistically significant at the $5 \%$ level (although the coefficient in the dollar specification has declined somewhat in magnitude and is no longer statistically significantly different from zero). In remaining columns of the table, coefficients on Treatment 3 in both panels further decline in magnitude, and in no case are they statistically significantly different from zero at conventional levels. ${ }^{37}$

These results do not allow us to tell whether the impact of Treatment 3 is truly only temporary (lasting no more than 18 months post-treatment), or whether persistent treatment impacts are obscured by the fact that the partner bank did market the Cuenta Unidos and Ahorro Directo accounts more broadly after the follow-up survey was concluded (roughly 12 months after the treatments were administered). ${ }^{38}$

\section{Impact on remittances}

Increases in savings in El Salvador that we have documented (in response to Treatment 3 in particular) could either reflect an increase in the recipient savings rate (keeping remittances constant) or, alternatively, increases in remittances sent by the migrant. We therefore examine impacts of the treatments on remittances sent by the migrant to El Salvador.

\footnotetext{
${ }^{37}$ Online Appendix Figures 1-4 provide month-by-month detail on savings balances by treatment group. Appendix Figure 1 displays monthly total savings balances, graphically depicting the pattern found in Table 6: balances in Treatment 3 being clearly higher through roughly months 12-18, after which balances in other treatment groups catch up. Appendix Figures 2 and 3 display balances in, respectively, joint (Cuenta Unidos) and migrant-only (Ahorro Directo) accounts. For each of these types of accounts offered by the project, it is clear that, after roughly the $12^{\text {th }}-18^{\text {th }}$ month post-treatment, balances rise in the control group and other treatment groups that were not originally offered these accounts by our research project. When it comes to savings balances in other accounts at the partner bank (shown in Appendix Figure 4), the pattern is slightly different, with Treatments 1 and 2 catching up with Treatment 3 but with balances in the control group remaining persistently lower. Overall it appears that catch up in the control group after months 12-18 is driven by control group savings in the project accounts (Cuenta Unidos and Ahorro Directo).

${ }^{38}$ While not dispositive, the time trend in savings in the comparison group (Treatment 0 ) is suggestive that the partner bank's broad marketing of these accounts did lead savings in the comparison group to catch up with those in the other treatments. The bottom row of Table 6, Panel B displays mean savings in the comparison group, which show a distinct rise in the 13-18-month post-treatment period (which appears persistent to later periods), coinciding with the timing of the partner bank's broad marketing of the new accounts.
} 
Results are presented in Table 7. Panel A presents main effects of Treatments 3, 2, and 1, while Panel B presents separate treatment effects for migrants with and without demand for control. The dependent variable in all columns is monthly remittances sent by the migrant.

The first and second columns of the table examine migrant remittances sent via the partner bank in, respectively, the full sample and the sample of migrants completing the followup survey. These are remittances sent to any recipient in El Salvador (we are not able to parse out only remittances sent to the primary remittance recipient.) ${ }^{39}$ The results in the second column are included to facilitate comparison with the third column, which examines remittances to the primary remittance recipient via all channels (not just the partner bank), as reported by the migrant in the follow-up survey. For neither sample is an identifiable effect of any treatment on remittances sent via the partner bank: all coefficients in Panel A are small in magnitude and none are statistically significantly different from zero. The same conclusion holds when the dependent variable is remittances that migrants report sending to primary remittance recipients in the follow-up survey (column 3). In Panel B where separate effects are estimated for migrants with and without demand for control, there also is no robust evidence of heterogeneous effects of any of the treatments on remittances.

In the context of our other findings, the lack of impact of the treatments on remittances suggests that the increases in savings we found (particularly due to Treatment 3) reflect an increase in the savings rate (holding constant the flow of remittances to El Salvador).

\section{Conclusion}

This paper expands our knowledge about financial decision-making by international migrants, and in particular on how they respond to improvements in their ability to monitor and control financial decision-making in the origin country. We implemented a field experiment that offered US-based Salvadoran migrants bank accounts that varied in the degree to which migrants could monitor and control savings in El Salvador-based accounts. We found that the treatment that offered migrants the greatest degree of control over El Salvador savings (offering both joint accounts and accounts in the migrant's name alone) led to substantial increases in savings at the partner bank. This increase in savings is likely due to enhanced control exerted by migrants; the effect of the treatment is significantly larger among migrants who report greater demand for such

\footnotetext{
${ }^{39}$ For the dependent variables in columns 1 and 2, all funds sent to El Salvador are counted as remittances, whether retrieved by the recipient in cash or sent directly to a bank account (and whether the bank account is joint with the migrant or in the name of someone in El Salvador only).
} 
control in the baseline survey. As a caveat, we note that there are no obvious welfare implications of our results. Increased control exerted by migrants may not necessarily lead to higher well-being on the part of family members in the origin household. Migrants may be pursuing objectives that they place in higher regard than do family members back home.

Another important result of the paper is that simply channeling remittances into bank accounts in the home country does not in itself promote savings accumulation. This is clearly demonstrated by the fact that one of our treatments - that did not offer joint accounts, and instead promoted opening and remitting into bank accounts in the name solely of someone in El Salvador - had no identifiable impact on savings. But when migrants are given the ability to monitor and control savings in the home country, the impact on savings accumulation is much larger. This insight should guide future efforts to facilitate savings accumulation in homecountry households that are connected with international migrants.

By showing the effects of an intervention that enhanced migrant control over savings in remittance-recipient households, this study also suggests some high-potential directions for future research. In particular, it should be fruitful to study the impacts of migrant control over other remittance uses that may have positive spillovers and wider development impacts, such as payments for schooling, health care, and investments in microenterprises.

\section{References}

Ashraf, N., "Spousal Control and Intra-Household Decision Making: An Experimental Study in the Philippines,” American Economic Review, Vol. 99, No. 4, September 2009.

Ashraf, Nava, Dean Karlan, and Wesley Yin, "Tying Odysseus to the Mast: Evidence from a Commitment Savings Product in the Philippines,” Quarterly Journal of Economics, May 2006. Aycinena, Diego, Claudia Martinez A. and Dean Yang, "The Impact of Remittance Fees on Remittance Flows: Evidence from a Field Experiment Among Salvadoran Migrants,” mimeo, University of Michigan, 2010.

Browning, M., and Chiappori, P.-A., "Efficient Intra-household Allocations: A General Characterisation and Empirical Tests,” Econometrica, 66 (6), 1998.

Chatterjee, Promothesh and Randall L. Rose, "Do Payment Mechanisms Change the Way Consumers Perceive Products?” Journal of Consumer Research, 38(6), April 2012. 
Chen, Joyce, “Migration and Imperfect Monitoring: Implications for Intra-household Allocation,” American Economic Review: Papers and Proceedings, May 2006.

Chin, A., L. Karkoviata, and N. Wilcox, “Impact of Bank Accounts on Migrant Savings and Remittances: Evidence from a Field Experiment,” mimeo, University of Houston, 2010.

De Laat, Joost, “Household Allocations and Endogenous Information,” mimeo, University of Quebec at Montreal, 2008.

Dercon, Stefan and Pramila Krishna, "In Sickness and in Health: Risk Sharing within Households in Rural Ethiopia,” Journal of Political Economy, Vol. 108, No. 4, August 2000.

Dubois, P. and E. Ligon, "Incentives and Nutrition for Rotten Kids: Intrahousehold Food Allocation in the Philippines,” mimeo, University of California (Berkeley), 2005.

Duflo, Esther. 2003. “Grandmothers and Granddaughters: Old Age Pension and Intra-Household Allocation in South Africa.” World Bank Economic Review. 17(1).

Goldstein, Markus Alain de Janvry, and Elisabeth Sadoulet, "Is a Friend in Need a Friend Indeed? Inclusion and Exclusion in Mutual Insurance Networks in Southern Ghana,” in Stefan Dercon (ed.) Insurance against Poverty, Oxford University Press, 2005.

Hertzberg, Andrew, “Exponential Individuals, Hyperbolic Households,” working paper, Columbia Business School, 2011.

Kinnan, Cynthia, “Distinguishing Barriers to Insurance in Thai Villages,” working paper, Northwestern University, 2011.

Laran, Juliano, Amy Dalton, and Eduardo Andrade, “The Curious Case of Behavioral Backlash: Why Brands Produce Priming Effects and Slogans Produce Reverse Priming Effects,” Journal of Consumer Research, 37, April 2011.

Lundberg, Shelly and Robert Pollak, “Separate Spheres Bargaining and the Marriage Market,” Journal of Political Economy, 101, 1993, pp. 988-1010.

Lusardi, Annamaria and Olivia S. Mitchell, “Financial Literacy and Planning: Implications for Retirement Wellbeing,” Working Paper, Pension Research Council, Wharton School, University of Pennsylvania, 2006.

Lusardi, A. and O.S. Mitchell, "Baby Boomer Retirement Security: The Roles of Planning, Financial Literacy, and Housing Wealth,” Journal of Monetary Economics, Vol. 54, 2007. Manser, M. and M. Brown, "Marriage and Household Decision-Making: A Bargaining Analysis,” International Economic Review, 21, 1980. 
Martinez, Claudia, "Intra-Household Allocation and Bargaining Power: Evidence from Chile,” Economic Development and Cultural Change, Vol. 61, No. 3, 2013.

McElroy, M. and M. Horney, "Nash-Bargained Household Decisions: Towards a Generalization of the Theory of Demand," International Economic Review, 22/2, 1981.

Orozco, Manuel, “The Remittance Marketplace: Prices, Policy, and Financial Institutions,” Pew Hispanic Center Report, 2004.

Pew Hispanic Center, Billions in Motion: Latino Immigrants, Remittances, and Banking.

Washington, DC: Pew Hispanic Center and Multilateral Investment Fund, 2002.

Platteau, Jean-Philippe, “Traditional Systems of Social Security and Hunger Insurance: Past Achievements and Modern Challenges,” in E. Ahmad, J. Dreze, J. Hills, and A. Sen (eds.), Social Security in Developing Countries, Oxford: Clarendon Press, 1991.

Rangel, Marcos, “Alimony Rights and Intrahousehold Allocation of Resources: Evidence from Brazil,” Economic Journal, Vol. 116, 2006, pp. 627-658.

Ratha, Dilip, “Workers' Remittances: An Important and Stable Source of External Development Finance,” in Global Development Finance 2003: Striving for Stability in Development Finance. Washington, DC: International Monetary Fund, 2003.

Schaner, Simone, “Intrahousehold Preference Heterogeneity, Commitment, and Strategic Savings: Theory and Evidence from Kenya,” working paper, Dartmouth College, 2011. Strauss, John and Duncan Thomas, "Human Resources: Empirical Modeling of Household and Family Decisions,” in Jere Behrman and T.N. Srinivasan, eds., Handbook of Development Economics. New York: North-Holland, 1995.

Terry, Donald F. and Steven R. Wilson, eds., Beyond Small Change: Making Migrant Remittances Count. Washington, DC: Inter-American Development Bank, 2005. Udry, Christopher, “Gender, Agricultural Productivity and the Theory of the Household”, Journal of Political Economy, 104, 1996.

World Bank, Global Economic Prospects 2006: Economic Implications of Remittances and Migration. Washington, DC, 2006.

World Bank, Close to Home: The Development Impact of Remittances in Latin America. Washington, DC, 2007.

Yang, Dean, “Migrant Remittances,” Journal of Economic Perspectives, Vol. 25, No. 3, Summer 2011, pp. 129-152. 
Figure 1: Cumulative distribution function of quartic root of total savings at partner bank, by treatment

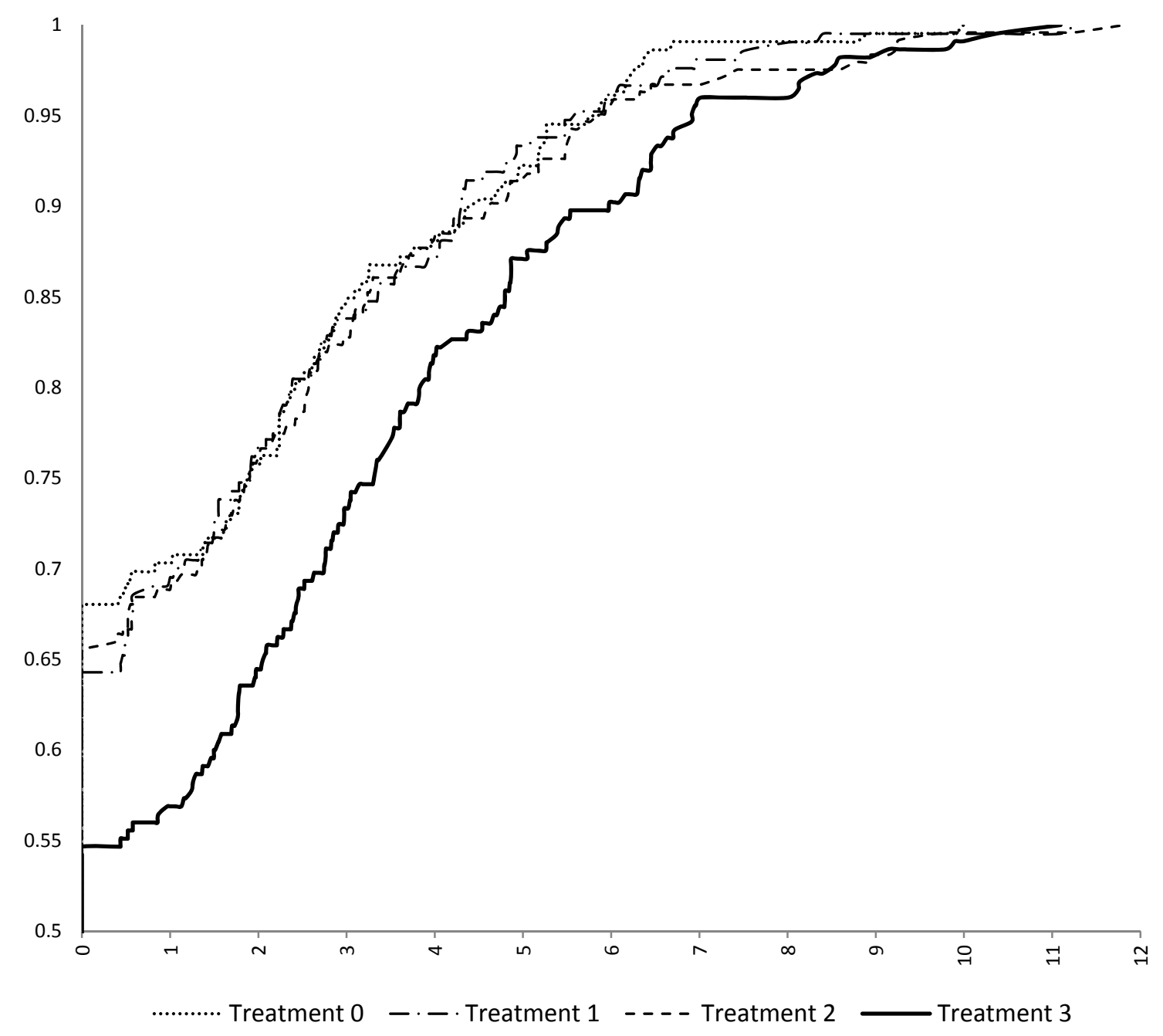

Note: CDF truncated at 0.5 on vertical axis. Variable depicted is identical to the dependent variable in regressions of Table 3, Panel A, column (d). 
Table 1: Summary statistics

Treatment indicators and stratification variables

Treatment 0 (no savings facility offered)

Treatment 1 (remittance recipient account only)

Treatment 2 (joint account)

Treatment 3 (joint + migrant account)

Migrant is female

Migrant has US bank account

Recipient is migrant's parent

Recipient is migrant's spouse

Recipient is migrant's child

Recipient is migrant's other relative

Migrant has been in US 0 - 5 years

Migrant has been in US 6-10 years

Migrant has been in US 11-15 years

\begin{tabular}{rrrrrr} 
Mean & Std. Dev. & 10th pct. & Median & 90th pct. & Num. Obs. \\
& & & & & \\
0.24 & 0.43 & 0 & 0 & 1 & 898 \\
0.23 & 0.42 & 0 & 0 & 1 & 898 \\
0.27 & 0.45 & 0 & 0 & 1 & 898 \\
0.25 & 0.43 & 0 & 0 & 1 & 898 \\
0.29 & 0.45 & 0 & 0 & 1 & 898 \\
0.63 & 0.48 & 0 & 1 & 1 & 898 \\
0.55 & 0.50 & 0 & 1 & 1 & 898 \\
0.11 & 0.31 & 0 & 0 & 1 & 898 \\
0.04 & 0.19 & 0 & 0 & 0 & 898 \\
0.30 & 0.46 & 0 & 0 & 1 & 898 \\
0.50 & 0.50 & 0 & 0 & 1 & 898 \\
0.40 & 0.49 & 0 & 0 & 1 & 898 \\
0.11 & 0.31 & 0 & 0 & 1 & 898 \\
& & & & & \\
5.57 & 3.60 & 1 & 5 & 11 & 898 \\
0.17 & 0.38 & 0 & 0 & 1 & 898 \\
30,999 & 56,292 & 11,700 & 24,960 & 48,822 & 865 \\
39,620 & 87,551 & 10,530 & 31,200 & 65,000 & 896 \\
8.53 & 4.17 & 2 & 9 & 12 & 865 \\
30.88 & 7.65 & 22 & 30 & 41 & 894 \\
4,990 & 4,124 & 1,200 & 3,900 & 9,600 & 898 \\
2,851 & 5,111 & 0 & 750 & 8,100 & 806 \\
0.007 & 0.082 & 0 & 0 & 0 & 894 \\
4.81 & 2.15 & 2 & 5 & 8 & 898 \\
0.59 & 0.49 & 0 & 1 & 1 & 897 \\
0.08 & 0.27 & 0 & 0 & 0 & 898 \\
0.23 & 0.42 & 0 & 0 & 1 & 898 \\
0.21 & 0.41 & 0 & 0 & 1 & 898 \\
0.15 & 0.35 & 0 & 0 & 1 & 898 \\
0.05 & 0.22 & 0 & 0 & 0 & 898 \\
0.51 & 0.50 & 0 & 1 & 1 & 898 \\
0.66 & 0.47 & 0 & 1 & 1 & 898 \\
0.64 & 0.48 & 0 & 1 & 1 & 898 \\
0.37 & 0.48 & 0 & 0 & 1 & 898 \\
0.46 & 0.50 & 0 & 0 & 1 & 897 \\
& & & & & \\
382 & 1,732 & 0 & 0 & 380 & 733 \\
3,182 & 2,787 & 900 & 2,400 & 6,000 & 725 \\
& & & & & \\
1.02 & 2.08 & 0 & 0 & 4.45 & 898 \\
243 & 1,085 & 0 & 0 & 391 & 898 \\
\hline & & & & &
\end{tabular}

Baseline variables from DC migrant survey

Migrant's years in the US

Migrant has El Salvador bank account

Migrant's annual income (US\$)

Migrant's household's annual income (US\$)

Migrant's years of education

Migrant's age

Migrant's annual remittances sent (US\$)

Migrant's total hh savings balance (US\$)

Migrant is US citizen

Migrant hh size in U.S.

Migrant is married or partnered

Past experience with direct payments

Sent funds to El Salvador for others to administer

Interested in direct payments to increase control

Aware of disagreements with recipients over remittance uses

Have had disagreements with recipients over remittance uses

Demand for control (union of above five indicators)

Correct answer to compound interest question

Correct answer to inflation question

Correct answer to mutual fund question

Tracks spending and budgets expenses

Baseline variables from El Salvador household survey

Recipient's total hh savings balance (US\$)

Recipient's annual remittances received (US\$)

(1)

Pre-treatment savings at partner bank

Savings balance, average over 12 months prior to treatment-quartic (US\$)

Savings balance, average over 12 months prior to treatment (US\$)

Notes: Survey data collected from Jun 2007 to Jan 2008 among Salvadoran migrants in Washington DC and from Nov 2007 to Jun 2008 among households in El Salvador identified as DC migrant's "primary remittance recipient". 
Table 2: Impact of treatments on account ownership at partner bank

(Ordinary least-squares estimates)

Dependent variable: Indicator for existence of given type of account at partner bank during 12 months post-treatment

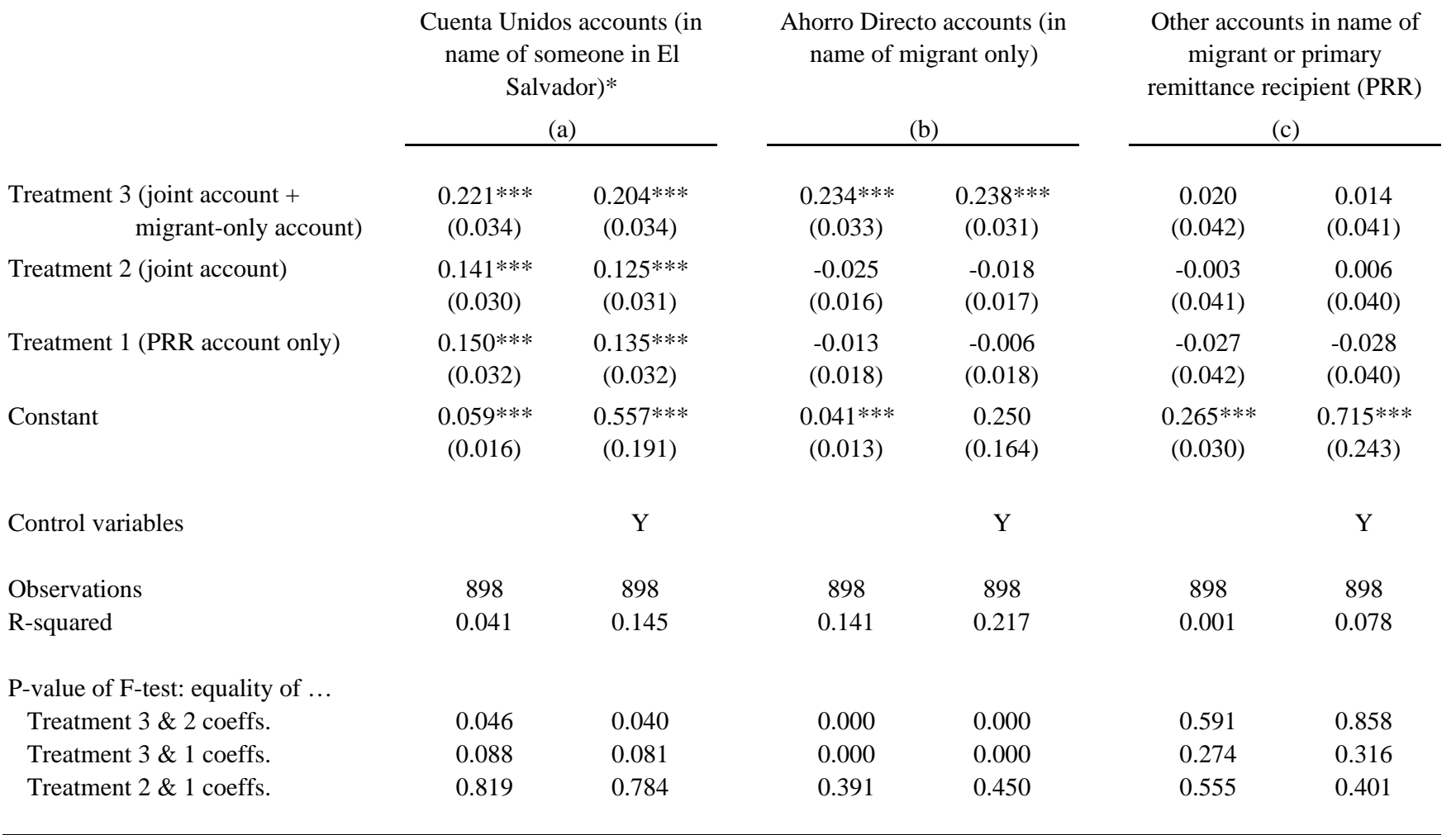

Robust standard errors in parentheses. * significant at 10\%; ** significant at 5\%; *** significant at $1 \%$

Notes: Dependent variable equal to 1 if migrant or remittance recipient has given type of project account with partner bank (Banco Agricola), 0 otherwise. Omitted treatment indicator is for Treatment 0 (comparison group). Control variables include: marketer fixed effects are for the specific individual (out of 9) who conducted the marketing visit; stratification cell fixed effects for each of 48 unique combinations of stratification variables: gender (male/female), having a US bank account (yes/no), relationship to remittance recipient (parent/child/spouse/other), and years in US category (0-5 years/6-10 years/11-15 years); treatment month fixed effects; indicator for migrant demand for control. Treatment months are Nov 2007 through Jul 2008 inclusive.

*Cuenta Unidos accounts opened with project assistance in Treatments 2 and 3 are all joint accounts shared by migrants and someone in El Salvador, while those opened in Treatment 1 are all accounts in name of primary remittance recipient (PRR) only. Some Cuenta Unidos accounts may have been opened without project assistance in any of the treatment groups, and in these cases the accounts may be in the name of PRRs alone or joint between migrants and someone in El Salvador. 
Table 3: Impact of treatments on savings in accounts at partner bank

(Ordinary least-squares estimates)

Dependent variable: Savings balance (US\$), average over 12 months post-treatment, in accounts of given type

Cuenta Unidos accounts (in Ahorro Directo accounts (in name of someone in El Salvador)* name of migrant only)
Other accounts (in name of migrant or primary remittance recipient)
In total across all accounts

(c)

$(d)=(a)+(b)+(c)$

\section{Panel A (quartic root)}

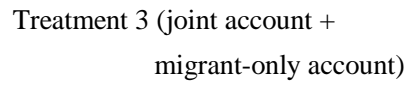

Treatment 2 (joint account)

Treatment 1 (PRR account only)

Constant

\section{Control variables}

Observations

R-squared

P-value of F-test: equality of ...

Treatment 3 \& 2 coeffs.

Treatment 3 \& 1 coeffs.

Treatment 2 \& 1 coeffs.

Mean of dep. var. in comparison group

\section{Panel B (in dollars)}

Treatment 3 (joint account + migrant-only account)

Treatment 2 (joint account)

Treatment 1 (PRR account only)

Constant

Control Variables

Observations

R-squared

P-value of F-test: equality of ...

Treatment 3 \& 2 coeffs.

Treatment 3 \& 1 coeffs.

Treatment 2 \& 1 coeffs.

$\begin{array}{ccc}79.770 & 106.543 & 28.978^{*} \\ (68.482) & (83.989) & (15.166) \\ 70.062 & 94.661^{*} & -9.074 \\ (45.054) & (55.237) & (6.920) \\ 12.693 & 27.980 & -5.605 \\ (13.961) & (21.121) & (7.211) \\ 16.005^{*} & 240.552 & 9.074 \\ (8.469) & (163.721) & (6.920)\end{array}$

$0.387 * * *$

(0.108)

$0.232 * *$

$0.184^{* *}$

(0.092)

$0.176^{* * *}$

(0.055)

$\mathrm{Y}$

Mean of dep. var. in comparison group
(0.101)

898
0.013


0.214
0.088
0.671

$\begin{array}{cc}0.354 * * * & 0.281 * * * \\ (0.114) & (0.089) \\ 0.231 * * & -0.079 * * \\ (0.109) & (0.039) \\ 0.162 * & -0.012 \\ (0.088) & (0.051) \\ 0.920 & 0.079 * * \\ (0.628) & (0.039)\end{array}$

$0.305 * * *$

(0.094)

$-0.057$

(0.047)

$-0.004$

(0.051)

0.004

(0.131)

\section{Y}

898

0.087

0.334

0.101

0.555

0.176

$$
\text { Y }
$$

898

0.003

898

0.035

0.905

0.329

0.208

$\mathrm{Y}$
898
0.117

0.000
0.000
0.091

0.079

0.282
$(0.198)$
0.035
$(0.177)$
-0.084
$(0.179)$
$0.887 * * *$
$(0.124)$

0.206

(0.192)

$0.705^{* * *}$

(0.215)

0.110

(0.193)

0.044

(0.193)

1.119 ***

(0.133)

(1.183)

Y

898

0.064

0.305

0.105

0.531

0.887

0.639 ***

(0.212)

0.102

(0.198)

0.001

(0.195)

2.818**

(1.184)

\section{Y}

898

0.082

0.220
0.072
0.514

0.514

1.119
0.017

0.004

$\begin{array}{ll}0.741 & 0.624\end{array}$

$\begin{array}{ccccc}32.533^{*} & 187.826^{*} & 142.479 & 296.574 * * & 281.555^{* *} \\ (17.131) & (106.129) & (101.002) & (126.380) & (132.572) \\ -6.996 & 86.995 & 25.354 & 147.983 & 113.018 \\ (8.159) & (109.439) & (110.911) & (119.543) & (126.260) \\ -5.802 & 38.339 & 1.988 & 45.426 & 24.166 \\ (8.338) & (101.573) & (102.704) & (102.511) & (105.030) \\ 6.610 & 160.836 * * * & 382.230 & 185.914^{* * *} & 629.391^{*} \\ (15.665) & (56.859) & (317.066) & (57.586) & (366.516)\end{array}$

$\begin{array}{cccccc} & Y & Y & & Y \\ 898 & 898 & 898 & 898 & 898 & 898 \\ 0.017 & 0.087 & 0.003 & 0.069 & 0.006 & 0.056\end{array}$

Robust standard errors in parentheses. * significant at 10\%; ** significant at 5\%; *** significant at $1 \%$

Notes: Dependent variables are averaged over end-of-month balances in US dollars. See Table 2 for other notes.

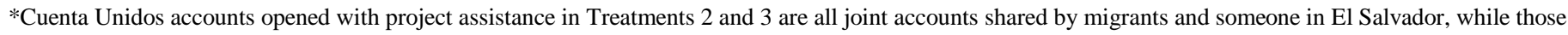

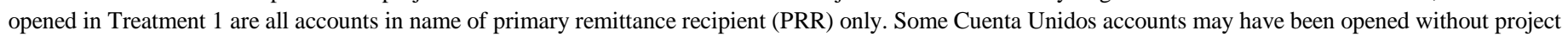

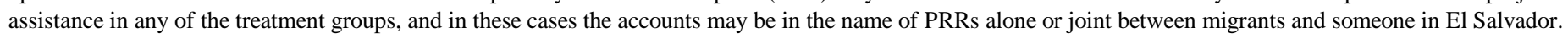


Table 4: Impact of treatments on savings reported by migrants in follow-up survey

(Ordinary least-squares estimates)

Dependent variable: Savings reported in follow-up survey (Mar - Jun 2009)

$\begin{array}{ccc}\text { Savings in El } & \text { Savings in the } & \text { Savings in cash } \\ \text { Salvador } & \text { U.S. } & \end{array}$

\section{Panel A (quartic root)}
(a)

(b)

(c)

$(\mathrm{d})=(\mathrm{a})+(\mathrm{b})+$

Treatment 3 (joint account + migrant-only account)

0.366

$0.711^{*}$

$-0.445^{* *}$

0.516

Treatment 2 (joint account)

$(0.302)$

$(0.387)$

(0.197)

$(0.436)$

0.463

0.227

$-0.080$

0.581

(0.316)

(0.360)

(0.202)

$(0.436)$

Treatment 1 (PRR account only)

$(0.293)$

0.173

$-0.066$

0.266

(0.362)

(0.433)

Control Variables

\section{Y}

Y

\section{Y}

Y

Observations

508

508

508

508

R-squared

0.127

0.167

0.147

0.149

P-value of F-test: equality of ...

Treatment $3 \& 2$ coeffs.

0.734

0.636

0.186

0.048

0.079

0.874

Treatment $3 \& 1$ coeffs.

0.442

0.156

0.949

0.556

Treatment $2 \& 1$ coeffs.

0.629

1.573

0.552

2.567

Panel B (in dollars)

\begin{tabular}{|c|c|c|c|c|}
\hline $\begin{array}{l}\text { Treatment } 3 \text { (joint account }+ \\
\text { migrant-only account) }\end{array}$ & $\begin{array}{c}382.002 \\
(271.230)\end{array}$ & $\begin{array}{c}450.125 \\
(356.568)\end{array}$ & $\begin{array}{c}-188.496 * * \\
(94.733)\end{array}$ & $\begin{array}{c}643.630 \\
(455.407)\end{array}$ \\
\hline Treatment 2 (joint account) & $\begin{array}{l}607.438 * \\
(342.681)\end{array}$ & $\begin{array}{l}-181.102 \\
(305.878)\end{array}$ & $\begin{array}{c}-19.996 \\
(100.273)\end{array}$ & $\begin{array}{c}406.340 \\
(468.693)\end{array}$ \\
\hline Treatment 1 (PRR account only) & $\begin{array}{c}193.795 \\
(242.484)\end{array}$ & $\begin{array}{c}-122.822 \\
(297.461)\end{array}$ & $\begin{array}{c}84.552 \\
(127.252)\end{array}$ & $\begin{array}{c}155.526 \\
(403.441)\end{array}$ \\
\hline Control Variables & $\mathrm{Y}$ & $\mathrm{Y}$ & $\mathrm{Y}$ & $\mathrm{Y}$ \\
\hline Observations & 508 & 508 & 508 & 508 \\
\hline R-squared & 0.087 & 0.142 & 0.102 & 0.119 \\
\hline \multicolumn{5}{|l|}{ P-value of F-test: equality of ... } \\
\hline Treatment 3 \& 2 coeffs. & 0.457 & 0.030 & 0.031 & 0.577 \\
\hline Treatment $3 \& 1$ coeffs. & 0.425 & 0.064 & 0.013 & 0.220 \\
\hline Treatment $2 \& 1$ coeffs. & 0.189 & 0.747 & 0.338 & 0.494 \\
\hline Mean of dep. var. in comparison group & 264.732 & 599.866 & 143.036 & 1007.634 \\
\hline
\end{tabular}

Robust standard errors in parentheses. * significant at 10\%; ** significant at 5\%; *** significant at $1 \%$

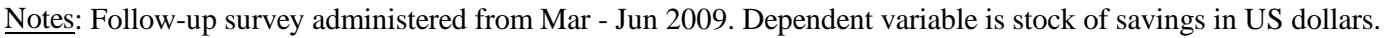
Omitted treatment indicator is for Treatment 0 (comparison group). Control variables include: marketer fixed effects are for the specific individual (out of 9) who conducted the marketing visit; stratification cell fixed effects for each of 48 unique combinations of stratification variables: gender (male/female), having a US bank account (yes/no), relationship to remittance recipient (parent/child/spouse/other), and years in US category (0-5 years/6-10 years/11-15 years); treatment month fixed effects; indicator for migrant demand for control. Treatment months are Nov 2007 through Jul 2008 inclusive. 
Table 5: Heterogeneity in treatment effects by baseline demand for control

(Ordinary least-squares estimates)

Dependent variable: Savings balance (US\$), average over 12 months post-treatment, in accounts of given type
Cuenta Unidos accounts (in Ahorro Directo accounts name of someone in El (in name of migrant only) Salvador)

Other accounts (in name of In total across all accounts migrant or primary remittance recipient)

\section{Panel A (quartic root)}

Treatment $3 *$ Demand for control

Treatment $3 *$ No demand for control

Treatment $2 *$ Demand for control

Treatment $2 *$ No demand for control

Treatment $1 *$ Demand for control

Treatment $1 *$ No demand for control

Control Variables

Observations

R-Squared

P-value of F-test: equality of interactions with

Treatment 3

Treatment 2

Treatment 1

Mean of dep. var. in comparison group

Migrants with demand for control

Migrants with no demand for control

\section{Panel B (in dollars)}

Treatment $3 *$ Demand for control

Treatment $3 *$ No demand for control

Treatment $2 *$ Demand for control

Treatment $2 *$ No demand for control

Treatment $1 *$ Demand for control

Treatment $1 *$ No demand for control

Control Variables

Observations

R-Squared

P-value of F-test: equality of interactions with

Treatment 3

Treatment 2

Treatment 1

Mean of dep. var. in comparison group Migrants with demand for control

Migrants with no demand for control (a)

(b)

(c)

0.331

$(0.261)$

0.070

$(0.279)$

0.047

(0.254)

$-0.054$

$(0.256)$

$-0.355$

(0.231)

0.099

(0.277)

$0.114^{*}$

0.186

\section{Y}

898

0.098

0.031

0.014

0.722

0.086

0.277

189.768

(148.826)

16.499

(27.879)

162.918*

(98.902)

24.894

(35.275)

14.106

(22.881)

36.222

(30.408)

$\mathrm{Y}$
898
0.039

0.212

0.173

0.541

13.637

18.672

$\mathrm{Y}$
898
0.126

0.025

0.100

0.024

0.129

0.022

-4.669
$(14.858)$
$72.243^{* *}$
$(29.198)$
-17.819
$(12.954)$
4.335
$(6.938)$
-18.008
$(14.363)$
7.967
$(6.471)$

$\mathrm{Y}$
898
0.101

0.101

\subsection{3}

0.098

0.086

16.907

0.252
Y

898

0.068

0.490

0.783

0.209

0.923

0.85
1.113

1.13

484.884**

(199.087)

61.729

(153.673)

263.588*

(155.977)

$-38.645$

(198.076)

$-69.687$

(98.699)

103.699

(171.613)

(168.831)

$\begin{array}{cc}\mathrm{Y} & \mathrm{Y} \\ 898 & 898 \\ 0.074 & 0.062\end{array}$

$0.089 \quad 0.077$

$0.411 \quad 0.228$

$0.494 \quad 0.352$

Robust standard errors in parentheses. * significant at $10 \%$; ** significant at $5 \%$; *** significant at $1 \%$

Notes: Dependent variables are averaged over end-of-month balances in US dollars. Regressions need not include main effects of Treatments 3 , 2 and 1 because they are fully interacted with "demand for control" and "no demand for control". See Table 2 for other notes. 
Table 6: Impact of treatments on savings at partner bank, over time

(Ordinary least-squares estimates)

Dependent variable: Savings balance (US\$), average over given months post-treatment, in total across all partner bank accounts

Post-treatment months:

$1-6$

$7-12$

13-18

$19-24$

25-30

31-36

$37-42$

$43-48$

\section{Panel A (quartic root)}

Treatment 3 (joint account + indiv. migrant account)

$\begin{array}{cccc}0.634^{* * *} & 0.626^{* * *} & 0.475^{* *} & 0.326 \\ (0.207) & (0.214) & (0.221) & (0.206) \\ 0.143 & 0.091 & -0.047 & -0.045 \\ (0.195) & (0.197) & (0.196) & (0.193) \\ 0.056 & -0.058 & -0.137 & -0.172 \\ (0.190) & (0.192) & (0.200) & (0.203)\end{array}$

0.275

$(0.207)$

0.322

(0.210)

$-0.091$

$-0.119$

$(0.197)$

(0.201)

$-0.150$

$-0.131$

(0.212)

(0.223)

0.255

(0.207)

$-0.122$

(0.199)

$-0.096$

$(0.220)$

Y

$\begin{array}{cr}Y & Y \\ 898 & 898\end{array}$

Observations

R-squared

P-value of F-test: equality of ...

Treatment 3 \& 2 coeffs.

Treatment $3 \& 1$ coeffs.

Treatment $2 \& 1$ coeffs.

Mean of dep. var. in comparison group

Panel B (in dollars)

Treatment 3 (joint account + indiv. migrant account)

Treatment 2 (joint account)

Treatment 1 (remittance recipient account)

Control Variables

Observations

R-squared

P-value of F-test: equality of ...

Treatment $3 \& 2$ coeffs.

Treatment $3 \& 1$ coeffs.

Treatment $2 \& 1$ coeffs.

Mean of dep. var. in comparison group

0.083

$\mathrm{Y} \quad \mathrm{Y}$

898

0.082

Y

898

0.074

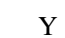

\section{8}

0.067

\section{Y}

898

0.064

0.017

0.006

0.655

0.075

0.024

0.544

0.075

0.061

0.787

1.124

1.122

1.112

1.112

\subsection{3}

0.052

0.958

0.074

0.132

0.903

1.051

1.056

$\begin{array}{cc}277.787 * * & 285.323 * \\ (120.166) & (156.322) \\ 152.104 & 73.933 \\ (122.947) & (135.507) \\ 40.049 & 8.284 \\ (96.619) & (119.421)\end{array}$

211.905

(227.437)

$-32.024$

(122.470)

7.155

(126.208)

213.830
$(219.450)$
37.460
$(129.029)$
107.273
$(127.078)$

153.626

(211.533)

25.950

(170.891)

203.372

203.372
$(183.632)$

$\begin{array}{cc}\mathrm{Y} & \mathrm{Y} \\ 898 & 898 \\ 0.034 & 0.036\end{array}$

31.484
$(169.174)$
-35.547
$(201.742)$
178.405
$(215.878)$

1.083

$$
\text { Y }
$$

898

Y

Y

898

0.033

0.034

$\mathrm{Y}$
898
0.048

20.687

(220.522)

$-64.035$

(215.868)

142.401

(210.993)

0.127

0.079

0.714

1.152

31.584

(274.700)

$-111.047$

(238.924)

56.479

(228.290)

$\begin{array}{cc}\mathrm{Y} & \mathrm{Y} \\ 898 & 898 \\ 0.045 & 0.046\end{array}$

\begin{tabular}{llllllll}
0.422 & 0.207 & 0.234 & 0.401 & 0.546 & 0.674 & 0.692 & 0.591 \\
0.079 & 0.077 & 0.302 & 0.603 & 0.833 & 0.471 & 0.572 & 0.922 \\
0.433 & 0.663 & 0.741 & 0.622 & 0.432 & 0.366 & 0.338 & 0.443 \\
& & & & & & & \\
165.620 & 206.209 & 288.509 & 230.890 & 248.745 & 301.652 & 304.683 & 357.046 \\
\hline
\end{tabular}

\footnotetext{
Robust standard errors in parentheses. * significant at $10 \%$; ** significant at $5 \%$; ** significant at $1 \%$
}

Notes: Dependent variables are averaged over end-of-month balances in US dollars. Omitted treatment indicator is for Treatment 0 (comparison group). Control variables include: marketer fixed effects are for the specific individual (out of 9) who conducted the marketing visit; stratification cell fixed effects for each of 48 unique combinations of stratification variables: gender (male/female), having a US bank account (yes/no), relationship to remittance recipient (parent/child/spouse/other), and years in US category (0-5 years/6-10 years/11-15 years); treatment month fixed effects; indicator for migrant demand for control. Treatment months are Nov 2007 through Jul 2008 inclusive. 
Table 7: Impact of treatments on remittances (sent into bank accounts or as cash)

(Ordinary least-squares estimates)

\section{Dependent variable: \\ Remittance recipient: \\ Remittance channel:}

Time Frame:

Sample:

Data Source:

Monthly remittances sent by migrant

\author{
Anyone in El Salvador \\ Partner bank
}

July 2008 to June 2009

Full Sample

Partner bank database
Anyone in El Salvador

Partner bank

July 2008 to June 2009

Migrants completing

follow-up survey

Partner bank database
Primary remittance recipient

All channels

July 2008 until follow-up survey

Migrants completing followup survey

Follow-up survey

\section{Panel A: Main effect of treatments}

\begin{tabular}{|c|c|c|c|}
\hline $\begin{array}{l}\text { Treatment } 3 \text { (joint account }+ \\
\text { migrant-only account) }\end{array}$ & $\begin{array}{c}10.659 \\
(18.778)\end{array}$ & $\begin{array}{l}18.132 \\
(24.477)\end{array}$ & $\begin{array}{r}35.940 \\
(52.405)\end{array}$ \\
\hline \multirow[t]{2}{*}{ Treatment 2 (joint account) } & -20.180 & -9.358 & -2.078 \\
\hline & $(16.061)$ & $(19.391)$ & $(33.161)$ \\
\hline \multirow[t]{2}{*}{ Treatment 1 (PRR account only) } & -24.121 & -31.648 & 5.365 \\
\hline & $(16.270)$ & (20.926) & $(37.339)$ \\
\hline Control variables & $\mathrm{Y}$ & $\mathrm{Y}$ & Y \\
\hline Observations & 898 & 560 & 560 \\
\hline R-squared & 0.149 & 0.199 & 0.092 \\
\hline \multicolumn{4}{|l|}{ P-value of F-test: equality of ... } \\
\hline Treatment 3 \& 2 coeffs. & 0.081 & 0.236 & 0.391 \\
\hline Treatment $3 \& 1$ coeffs. & 0.053 & 0.035 & 0.528 \\
\hline Treatment $2 \& 1$ coeffs. & 0.781 & 0.261 & 0.810 \\
\hline Mean of dep. var. in comparison group & 71.283 & 82.423 & 239.954 \\
\hline \multicolumn{4}{|c|}{ Panel B: Separate treatment effects for migrants with and without baseline demand for control } \\
\hline \multirow[t]{2}{*}{ Treatment $3 *$ Demand for control } & -5.036 & -8.904 & -10.517 \\
\hline & $(29.416)$ & $(33.463)$ & $(53.487)$ \\
\hline \multirow[t]{2}{*}{ Treatment $3 *$ No demand for control } & 27.516 & 47.373 & 88.036 \\
\hline & $(20.963)$ & $(31.321)$ & $(86.988)$ \\
\hline \multirow[t]{2}{*}{ Treatment $2 *$ Demand for control } & -30.120 & -2.136 & -15.025 \\
\hline & $(27.596)$ & $(32.783)$ & $(57.674)$ \\
\hline \multirow[t]{2}{*}{ Treatment $2 *$ No demand for control } & -9.584 & -15.412 & 12.517 \\
\hline & $(16.446)$ & $(25.576)$ & $(38.312)$ \\
\hline \multirow[t]{2}{*}{ Treatment $1 *$ Demand for control } & -36.302 & $-59.460 *$ & 2.512 \\
\hline & $(27.427)$ & (31.719) & 61.83 \\
\hline \multirow[t]{2}{*}{ Treatment $1 *$ No demand for control } & -11.237 & -1.655 & 14.382 \\
\hline & $(19.254)$ & (31.352) & $(36.958)$ \\
\hline Control variables & $\mathrm{Y}$ & $\mathrm{Y}$ & $\mathrm{Y}$ \\
\hline Observations & 898 & 560 & 560 \\
\hline R-squared & 0.150 & 0.204 & 0.094 \\
\hline \multicolumn{4}{|c|}{ P-value of F-test: equality of interactions with } \\
\hline Treatment 3 & 0.355 & 0.193 & 0.310 \\
\hline Treatment 2 & 0.529 & 0.765 & 0.703 \\
\hline Treatment 1 & 0.469 & 0.222 & 0.812 \\
\hline \multicolumn{4}{|l|}{ Mean of dep. var. in comparison group } \\
\hline Migrants with demand for control & 91.473 & 99.412 & 277.754 \\
\hline Migrants with no demand for control & 48.545 & 62.213 & 194.986 \\
\hline
\end{tabular}

Robust standard errors in parentheses. * significant at 10\%; ** significant at 5\%; *** significant at $1 \%$

Notes -- Dependent variables are monthly remittances in US dollars. For the dependent variables in columns 1 and 2, all funds sent to El Salvador are counted as remittances, whether retrieved by the recipient in cash or sent directly to a bank account. Follow-up survey administered from Mar - Jun 2009. Omitted treatment indicator is for Treatment 0 (comparison group). Control variables include: marketer fixed effects are for the specific individual (out of 9) who conducted the marketing visit; stratification cell fixed effects for each of 48 unique combinations of stratification variables: gender (male/female), having a US bank account (yes/no), relationship to remittance recipient (parent/child/spouse/other), and years in US category (0-5 years/6-10 years/11-15 years); treatment month fixed effects; indicator for migrant demand for control. Treatment months are Nov 2007 through Jul 2008 inclusive. 


\section{NOT FOR PUBLICATION}

Online Appendix

for:

Savings in Transnational Households: A Field Experiment Among Migrants from El Salvador

By Nava Ashraf, Diego Aycinena, Claudia Martinez, and Dean Yang

\section{Appendix A: Marketing Scripts for Treatments 0, 1, 2, and 3}

Treatment 0: comparison group, not offered any new savings accounts or account-opening assistance

Initiate conversation with questions regarding client's preferences for money sending and saving services. For example:

- Do your family members currently save money?

- Which service providers do they currently utilize to send money?

- What type of transfer do you use, traditional remittance (with code/password) or remittance by credit to an account?

- Why do you use these services?

- What difficulties does your family member have in picking up/receiving the money that you send?

If they send money through traditional remittance (with code/password):

Did you know that besides sending money to your family via traditional remittance, there is a more practical, less costly option?

The option to which I am referring is "remittance by credit to an account". Let me explain why this option offers more advantages than a traditional remittance.

As you may know, when you send money via a traditional remittance, your family receives a code or password to take to a Banco Agrícola branch and wait in line to receive the remittance. By contrast, when you send money via a "remittance by credit to an account", you obtain the following advantages:

- Access to funds through a debit card: Your remittance recipient can access the funds in the account through a debit card. This way, should your remittance recipient need money immediately you will no longer have to worry about going to send money right away since he/she will now have money available in this account.

- Direct deposit of your remittance to this account: Remitting into an account facilitates your remittance recipient receiving the money you send: no longer will he/she have to go to the bank and wait in line to receive it or run the risk of losing the code/pin number. He/she can use any ATM to take out money using a debit card from anywhere in El Salvador.

Treatment 1: offer of remittance recipient account 
Initiate conversation with questions regarding client's preferences for money sending and saving services. For example:

- Do your family members currently save money?

- Which service providers do they currently utilize to send money?

- What type of transfer do you use, traditional remittance (with code/password) or remittance by credit to an account?

- Why do you use these services?

- What difficulties does your family member have in picking up/receiving the money that you send?

I come to present to you a service which will allow your remittance recipient to obtain a savings account courtesy of Banco Agrícola. This account offers you the following advantages:

- Savings for your remittance recipient in El Salvador: Your remittance recipient will be able to open a savings account in his/her name in El Salvador through Banco Agrícola.

- Access to funds through a debit card: Your remittance recipient can access the funds in the account through a debit card. This way, should your remittance recipient need money immediately you will no longer have to worry about going to send money right away since he/she will now have money available in this account.

- Direct deposit of your remittance to this account: Remitting into an account facilitates your remittance recipient receiving the money you send: no longer will he/she have to go to the bank and wait in line to receive it or run the risk of losing the code/pin number. He/she can use any ATM to take out money using a debit card from anywhere in El Salvador.

Treatment 2: offer of joint account (Cuenta Unidos)

Initiate conversation with questions regarding client's preferences for money sending and saving services. For example:

- Do your family members currently save money?

- Which service providers do they currently utilize to send money?

- What type of transfer do you use, traditional remittance (with code/password) or remittance by credit to an account?

- Why do you use these services?

- What difficulties does your family member have in picking up/receiving the money that you send?

I come to present to you a service which will allow your remittance recipient to obtain a "Cuenta Unidos” courtesy of Banco Agrícola. This account offers you the following advantages:

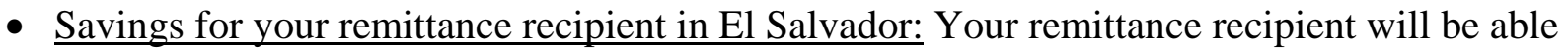
to open a savings account in his/her name in El Salvador through Banco Agrícola.

- Both your remittance recipient and you will be able to verify the balance on the account: This account will allow you to check the balance on the account through a service provided by a call center. 
- Access to funds for you and your remittance recipient through a debit card: Both you and your remittance recipient will have access to the funds in the account through a debit card. This way, should your remittance recipient need money immediately you will no longer have to worry about going to send money right away since he/she will now have money available in this account. Likewise, should you need money in the United States, you will also have access to funds from this account through the use of this debit card.

- Direct deposit of your remittance to this account: Remitting into an account facilitates your remittance recipient receiving the money you send: no longer will he/she have to go to the bank and wait in line to receive it or run the risk of losing the code/pin number. He/she can use any ATM to take out money using a debit card from anywhere in El Salvador.

Treatment 3: offer of joint account (Cuenta Unidos) and migrant-only account (Ahorro Directo)

Initiate conversation with questions regarding client's preferences for money sending and saving services. For example:

- Do your family members currently save money?

- Which service providers do they currently utilize to send money?

- What type of transfer do you use, traditional remittance (with code/password) or remittance by credit to an account?

- Why do you use these services?

- What difficulties does your family member have in picking up/receiving the money that you send?

I come to present to you a service which will allow your remittance recipient to obtain a "Cuenta Unidos” courtesy of Banco Agrícola. This account offers you the following advantages:

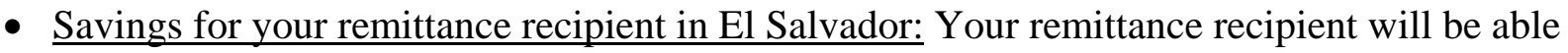
to open a savings account in his/her name in El Salvador through Banco Agrícola.

- Both your remittance recipient and you will be able to verify the balance on the account: This account will allow you to check the balance on the account through a service provided by a call center.

- Access to funds for you and your remittance recipient through a debit card: Both you and your remittance recipient will have access to the funds in the account through a debit card. This way, should your remittance recipient need money immediately you will no longer have to worry about going to send money right away since he/she will now have money available in this account. Likewise, should you need money in the United States, you will also have access to funds from this account through the use of this debit card.

- Direct deposit of your remittance to this account: Remitting into an account facilitates your remittance recipient receiving the money you send: no longer will he/she have to go to the bank and wait in line to receive it or run the risk of losing the code/pin number. He/she can use any ATM to take out money using a debit card from anywhere in El Salvador.

Present Ahorro Directo:

As part of this promotion, with the opening of a "Cuenta Unidos", you will also have the option of opening a private individual account, "Ahorro Directo", over which no one but yourself will 
have access or control, not even the person you are sharing Cuenta Unidos with. No one else except you will be able to check account balances or make withdrawals from this account, and no one else has to know that this account exists. It is exclusively yours.

Before describing the benefits of this account, let me ask you a few questions. Consult with the client's preferences and experiences in regards to the management of his/her money. For example:

- How much control do you have over the management of your finances in El Salvador?

- Do you save money now? How do you keep those savings? Do you save in the US or in El Salvador?

- What methods do you use to access your funds when you visit El Salvador?

- Have you considered the convenience of having a savings account in El Salvador for the future?

With the Ahorro Directo, you will have exclusive control over your money in El Salvador. This product will be very beneficial to you in the management of your finances for the following reasons:

- You will have the power to personally manage your money in El Salvador: You will have the opportunity to open a savings account in El Salvador in your name from here, over which only you will have access or control.

- You will never again have to use an intermediary to save money for you: If you save money through money transfers to your family or friends, with the opening of this account you will be able to make money transfers directly to your account without having to ask someone else any favors. In other words, you will be sending remittances to your own account instead of sending to someone else.

- You will benefit from the added security: Through the use of this product you will have access to your money in El Salvador as well as in the United States. This offers you important advantages, since you will not only be saving for your future, but you will also have the money available from any Banco Agricola branch in El Salvador in case you travel to El Salvador. In addition, this account includes a debit card, so you will no longer have to carry large amounts of cash with you to El Salvador, improving your personal security.

- It will be easy for you to check your account balance: This account will also allow you to check your balance through a call center. 


\section{Appendix Figure 1: Total savings balances at partner bank, by post-treatment month}

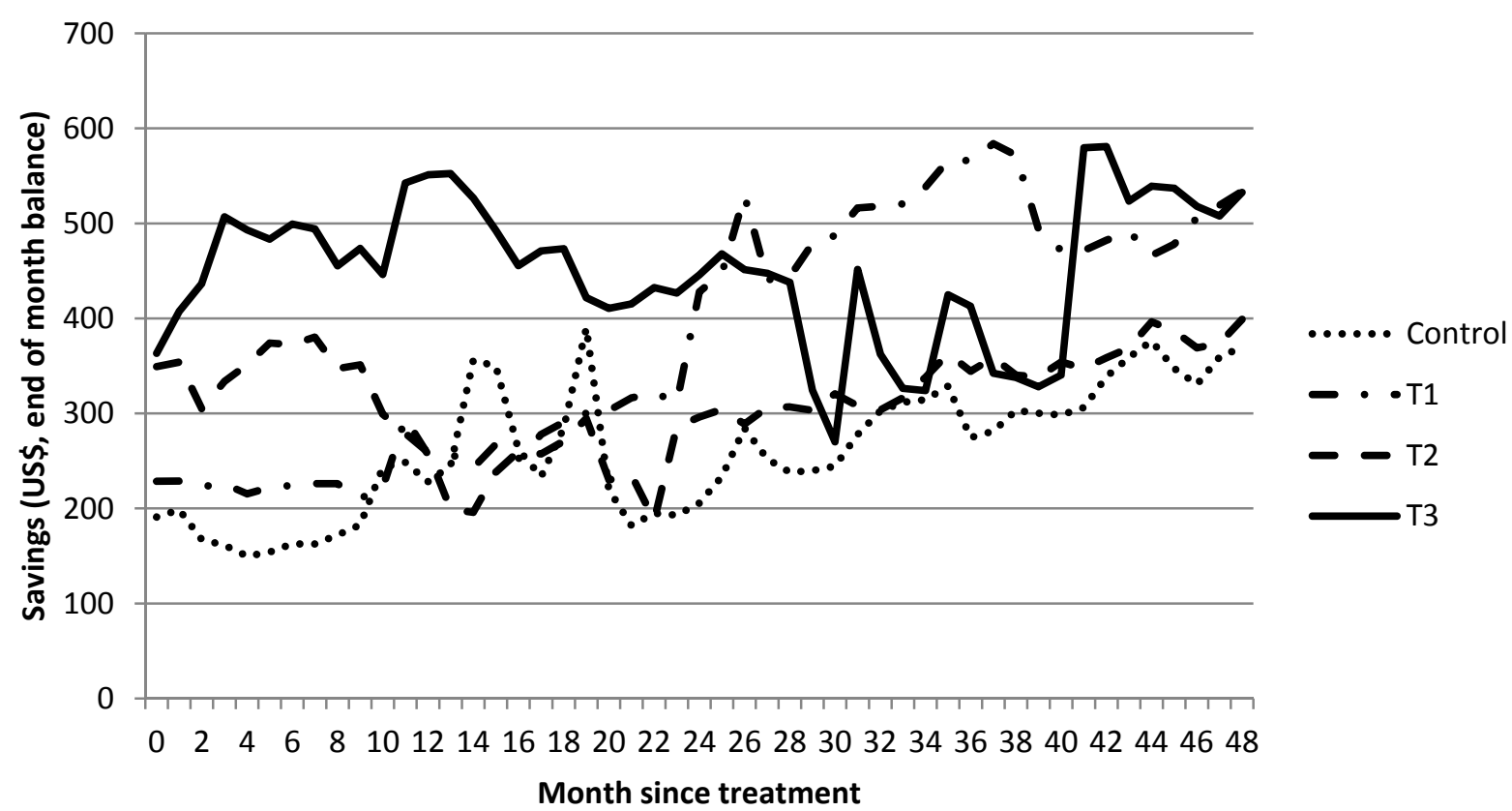

Notes: Variable depicted is savings balance (US\$, end of month) in given month since treatment, in total across all partner bank accounts. T1=treatment 1 (PRR account only), T2=treatment 2 (joint account), T3=treatment 3 (joint account + migrant-only account).

\section{Appendix Figure 2: Joint account (Cuenta Unidos) savings balances at partner bank, by post-treatment month}

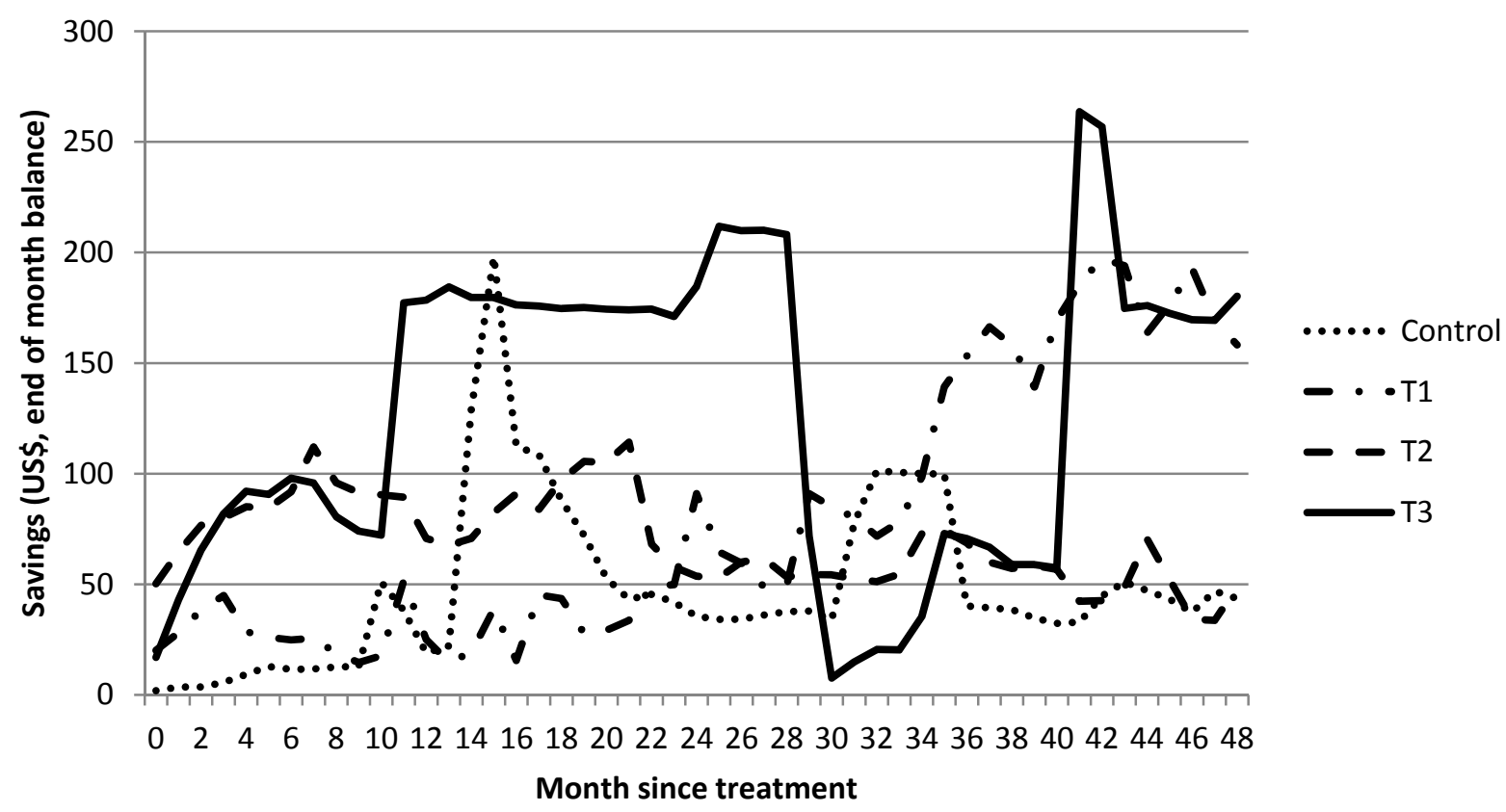

Notes: Variable depicted is joint account (Cuenta Unidos) savings balance (US\$, end of month) in given month since treatment. See Appendix Figure 1 for other notes. 
Appendix Figure 3: Migrant-only account (Ahorro Directo) savings balances at partner bank, by post-treatment month

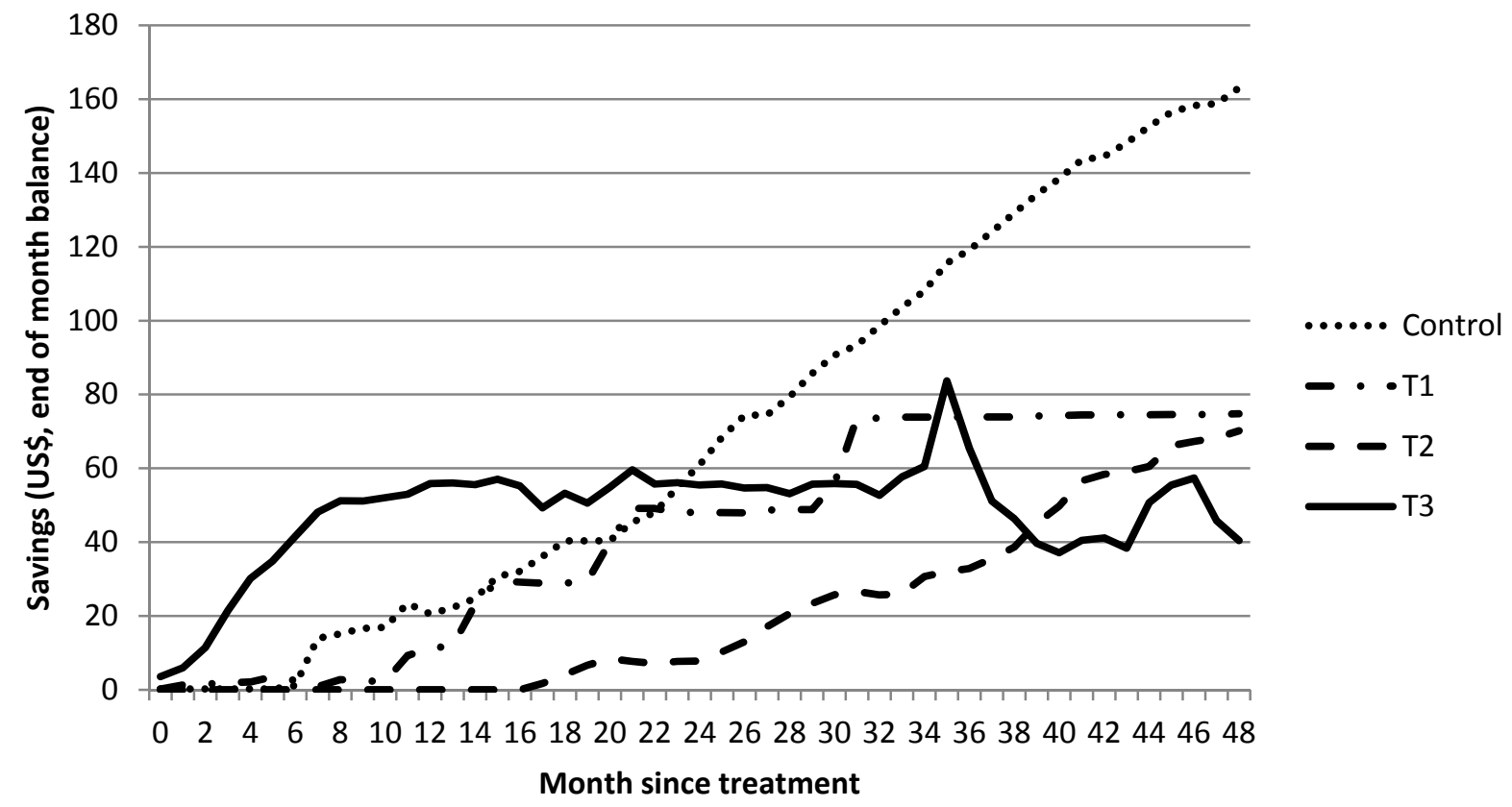

Notes: Variable depicted is migrant-only account (Ahorro Directo) savings balance (US\$, end of month) in given month since treatment. See Appendix Figure 1 for other notes.

\section{Appendix Figure 4: Savings balances in other accounts at partner bank, by post-treatment month}

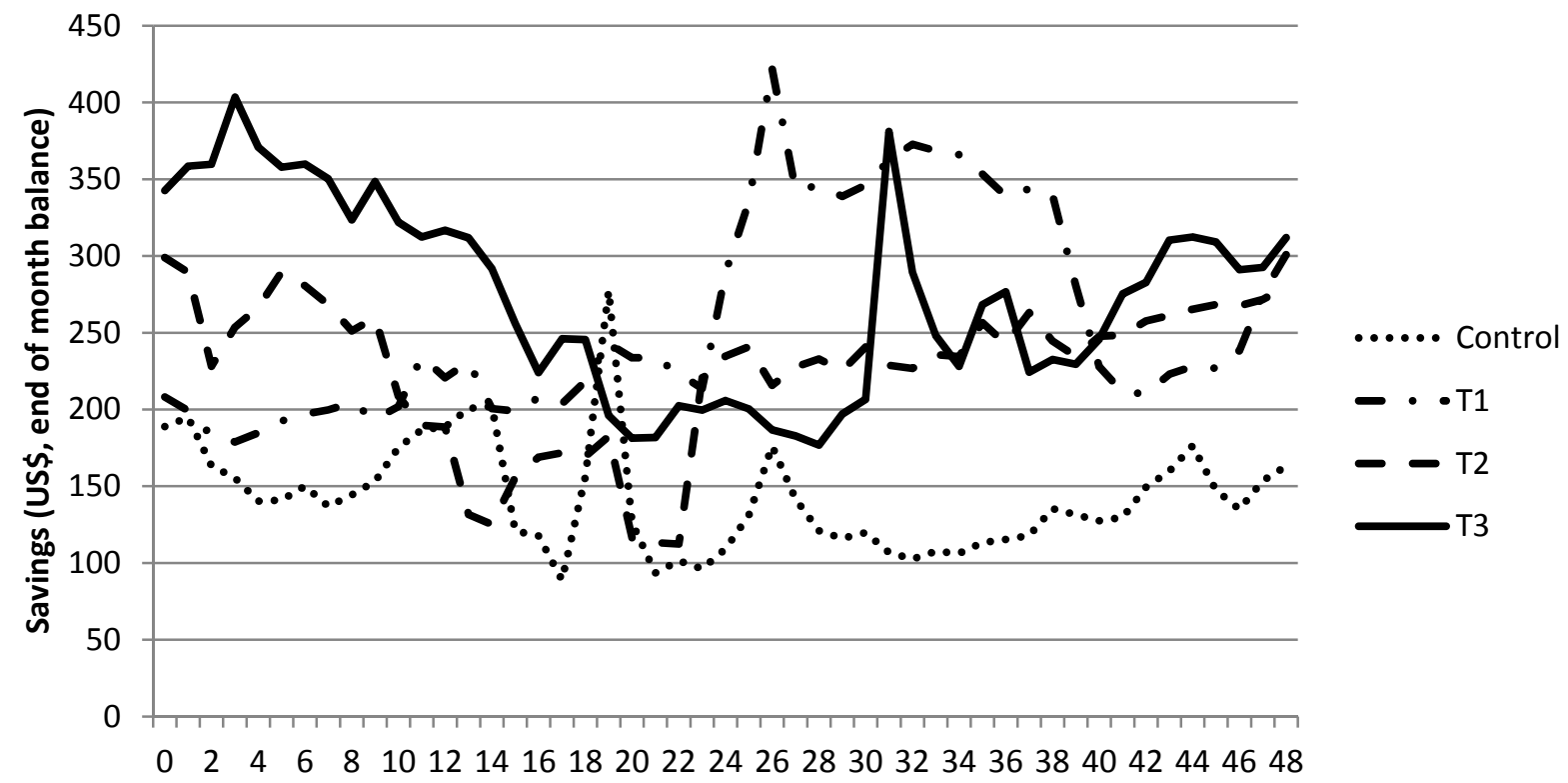

Notes: Variable depicted is savings balance (US\$, end of month) in given month since treatment in other accounts (neither Cuenta Unidos nor Ahorro Directo). See Appendix Figure 1 for other notes. 
Appendix Table 1: Comparison of means, study participants vs. DC-area Salvadorans and Hispanics in US Census

\begin{tabular}{|c|c|c|c|c|}
\hline \multirow{2}{*}{$\begin{array}{r}\text { Data source: } \\
\text { Sample restriction: }\end{array}$} & \multirow[t]{2}{*}{ Baseline survey } & \multicolumn{3}{|c|}{ US Census 2000} \\
\hline & & Salvadoran-born & $\begin{array}{l}\text { Salvadoran-born, } \\
\text { not US citizen }\end{array}$ & $\begin{array}{c}\text { Hispanic, not US } \\
\text { citizen }\end{array}$ \\
\hline Fraction male & 0.71 & 0.57 & 0.57 & 0.57 \\
\hline \multicolumn{5}{|l|}{ el A: Men } \\
\hline Age & $\begin{array}{l}30.34 \\
(7.36)\end{array}$ & $\begin{array}{l}30.34 \\
(8.87)\end{array}$ & $\begin{array}{l}30.25 \\
(8.84)\end{array}$ & $\begin{array}{l}30.62 \\
(9.13)\end{array}$ \\
\hline Migrant has been in US 0-5 years & 0.49 & 0.33 & 0.35 & 0.45 \\
\hline Migrant has been in US $6-10$ years & 0.40 & 0.29 & 0.29 & 0.28 \\
\hline Migrant has been in US $11-15$ years & 0.10 & 0.38 & 0.36 & 0.27 \\
\hline No Education & 0.07 & 0.13 & 0.13 & 0.09 \\
\hline Some Education, no degree & 0.63 & 0.60 & 0.61 & 0.52 \\
\hline High School Degree or more & 0.30 & 0.27 & 0.25 & 0.39 \\
\hline Migrant is US citizen & 0.00 & 0.10 & 0.00 & 0.00 \\
\hline Migrant is married or partnered & 0.53 & 0.45 & 0.44 & 0.47 \\
\hline Sample Size & 638 & 1,933 & 1,735 & 4,427 \\
\hline \multicolumn{5}{|l|}{ el B: Women } \\
\hline Age & $\begin{array}{l}32.20 \\
(8.19)\end{array}$ & $\begin{array}{l}31.71 \\
(9.52)\end{array}$ & $\begin{array}{l}31.66 \\
(9.42)\end{array}$ & $\begin{array}{l}32.59 \\
(9.98)\end{array}$ \\
\hline Migrant has been in US 0-5 years & 0.51 & 0.29 & 0.31 & 0.40 \\
\hline Migrant has been in US 6-10 years & 0.37 & 0.34 & 0.35 & 0.32 \\
\hline Migrant has been in US $11-15$ years & 0.12 & 0.37 & 0.34 & 0.28 \\
\hline No Education & 0.08 & 0.13 & 0.13 & 0.08 \\
\hline Some Education, no degree & 0.56 & 0.58 & 0.60 & 0.46 \\
\hline High School Degree or more & 0.36 & 0.30 & 0.27 & 0.46 \\
\hline Migrant is US citizen & 0.01 & 0.12 & 0.00 & 0.00 \\
\hline Migrant is married or partnered & 0.73 & 0.57 & 0.57 & 0.59 \\
\hline Sample Size & 260 & 1,453 & 1,259 & 3,263 \\
\hline
\end{tabular}

Note: US Census 2000 data are IPUMS 5\% sample, restricted to individuals aged 18-65 in the metro Washington DC area (including MD and VA suburbs). All variables other than age are indicator variables. Standard deviation in parentheses for age variable. 
Baseline stratification variables Migrant is female

Migrant has US bank accoun

Recipient is migrant's parent

Recipient is migrant's spouse

Recipient is migrant's child

Recipient is migrant's other relative

Migrant has been in US 0-5 years

Migrant has been in US 6-10 years

Migrant has been in US 11-15 years

Baseline survey variables

Migrant's years in the US

Migrant has El Salvador bank account

Migrant's household's annual income (US\$)

Migrant's years of education

Migrant's age

Migrant's annual remittances sent (US\$)

Migrant's total hh savings balance (US\$)

Migrant is US citizen

Migrant hh size in U.S.

Migrant is married or partnered

Past experience with direct payments

Sent funds to El Salvador for others to administer

Interested in direct payments to increase control

Aware of disagreements with recipients over remittance uses

Have had disagreements with recipients over remittance uses

Demand for control (union of above five indicators)

Correct answer to compound interest question

Correct answer to inflation question

Correct answer to mutual fund question

Baseline variables from El Salvador household survey

Recipient's total hh savings balance (US\$)

Recipient's annual remittances received (US\$)

Pre-treatment savings at partner bank

Quartic root of savings balance, average over 12 months prior to treatment

Savings balance, average over 12 months prior to treatment (US\$)

Atrition from follow-up survey

Attrition from US follow up savings data
Migrant's annual income (US\$)

Tracks spending and budgets expenses

\begin{tabular}{|c|c|c|c|}
\hline \multicolumn{4}{|c|}{ Treatment group } \\
\hline 0 & 1 & 2 & 3 \\
\hline 0.26 & 0.31 & 0.31 & 0.28 \\
\hline 0.61 & 0.61 & 0.66 & 0.63 \\
\hline 0.55 & 0.55 & 0.54 & 0.56 \\
\hline 0.14 & 0.09 & 0.11 & 0.09 \\
\hline 0.05 & 0.04 & 0.02 & 0.03 \\
\hline 0.26 & 0.31 & 0.33 & 0.32 \\
\hline 0.52 & 0.49 & 0.48 & 0.51 \\
\hline 0.39 & 0.40 & 0.41 & 0.38 \\
\hline 0.10 & 0.10 & 0.11 & 0.11 \\
\hline 5.42 & 5.47 & 5.76 & 5.59 \\
\hline 0.16 & 0.15 & 0.18 & 0.20 \\
\hline 30,669 & 36,587 & 29,108 & 28,109 \\
\hline 36,355 & 42,264 & 42,376 & 37,319 \\
\hline 8.62 & 8.15 & 8.94 & 8.35 \\
\hline 30.61 & 31.05 & 31.02 & 30.84 \\
\hline 5,451 & 4,876 & 4,689 & 4,974 \\
\hline 2,942 & 3,080 & 2,544 & 2,883 \\
\hline 0.00 & 0.00 & 0.01 & 0.01 \\
\hline 4.72 & 5.07 & 4.84 & 4.62 \\
\hline 0.54 & 0.58 & 0.62 & 0.60 \\
\hline 0.08 & 0.08 & 0.07 & 0.08 \\
\hline 0.23 & 0.20 & 0.25 & 0.24 \\
\hline 0.21 & 0.24 & 0.20 & 0.19 \\
\hline 0.16 & 0.15 & 0.14 & 0.13 \\
\hline 0.05 & 0.07 & 0.05 & 0.04 \\
\hline 0.53 & 0.49 & 0.49 & 0.52 \\
\hline 0.64 & 0.66 & 0.67 & 0.68 \\
\hline 0.61 & 0.66 & 0.63 & 0.68 \\
\hline 0.41 & 0.37 & 0.34 & 0.36 \\
\hline 0.46 & 0.50 & 0.43 & 0.46 \\
\hline 249 & 543 & 274 & 459 \\
\hline 3136 & 3112 & 3244 & 3224 \\
\hline 0.97 & 0.97 & 0.94 & 1.18 \\
\hline 229 & 232 & 200 & 315 \\
\hline 0.49 & 0.45 & 0.39 & 0.42 \\
\hline
\end{tabular}

P-value of F-test ...

\begin{tabular}{|c|c|c|c|c|}
\hline \multicolumn{4}{|c|}{ P-value of F-test ... } & \multirow[b]{2}{*}{ Num. of Obs } \\
\hline $\begin{aligned} \mathrm{T} 0 & =\mathrm{T} 1=\mathrm{T} 2 \\
& =\mathrm{T} 3\end{aligned}$ & $\mathrm{~T} 1=\mathrm{T} 0$ & $\mathrm{~T} 2=\mathrm{T} 0$ & $\mathrm{~T} 3=\mathrm{T} 0$ & \\
\hline 0.556 & 0.226 & 0.266 & 0.720 & 898 \\
\hline 0.590 & 0.883 & 0.209 & 0.676 & 898 \\
\hline 0.949 & 0.998 & 0.740 & 0.802 & 898 \\
\hline 0.317 & 0.104 & 0.331 & 0.093 & 898 \\
\hline 0.480 & 0.757 & 0.185 & 0.343 & 898 \\
\hline 0.326 & 0.184 & 0.091 & 0.163 & 898 \\
\hline 0.811 & 0.604 & 0.389 & 0.919 & 898 \\
\hline 0.893 & 0.729 & 0.638 & 0.824 & 898 \\
\hline 0.927 & 0.768 & 0.523 & 0.611 & 898 \\
\hline 0.764 & 0.904 & 0.330 & 0.635 & 898 \\
\hline 0.500 & 0.632 & 0.571 & 0.329 & 898 \\
\hline 0.555 & 0.452 & 0.481 & 0.285 & 865 \\
\hline 0.782 & 0.448 & 0.466 & 0.736 & 896 \\
\hline 0.213 & 0.271 & 0.415 & 0.506 & 865 \\
\hline 0.929 & 0.567 & 0.553 & 0.761 & 894 \\
\hline 0.314 & 0.187 & 0.062 & 0.268 & 898 \\
\hline 0.747 & 0.796 & 0.415 & 0.905 & 806 \\
\hline 0.112 & 0.317 & 0.083 & 0.156 & 894 \\
\hline 0.198 & 0.104 & 0.546 & 0.625 & 898 \\
\hline 0.329 & 0.467 & 0.075 & 0.211 & 897 \\
\hline 0.940 & 0.898 & 0.743 & 0.792 & 898 \\
\hline 0.525 & 0.344 & 0.665 & 0.860 & 898 \\
\hline 0.695 & 0.489 & 0.893 & 0.622 & 898 \\
\hline 0.768 & 0.633 & 0.537 & 0.289 & 898 \\
\hline 0.433 & 0.257 & 0.976 & 0.587 & 898 \\
\hline 0.749 & 0.414 & 0.368 & 0.840 & 898 \\
\hline 0.841 & 0.691 & 0.581 & 0.366 & 898 \\
\hline 0.518 & 0.332 & 0.667 & 0.160 & 898 \\
\hline 0.490 & 0.399 & 0.121 & 0.360 & 898 \\
\hline 0.617 & 0.480 & 0.531 & 0.982 & 897 \\
\hline 0.305 & 0.114 & 0.846 & 0.217 & 733 \\
\hline 0.957 & 0.929 & 0.731 & 0.769 & 725 \\
\hline 0.621 & 0.963 & 0.896 & 0.283 & 898 \\
\hline 0.711 & 0.980 & 0.767 & 0.393 & 898 \\
\hline 0.132 & 0.451 & 0.024 & 0.133 & 898 \\
\hline
\end{tabular}

Notes -- Table presents means of key variables for each treatment group prior to treatment. P-value is for F-test of equality of means across treatment groups. The first 9 variables listed in table are stratification variables: migrants were first sorted into 48 cells (based on gender, US bank account ownership, relationship to remittance recipient, and years on US category) before randomization into treatments 0 , 1, 2, or 3. Savings figures reported in US dollars. 
Baseline stratification variables Migrant is female

Migrant has US bank account

Recipient is migrant's parent

Recipient is migrant's spouse

Recipient is migrant's child

Recipient is migrant's other relative

Migrant has been in US 0-5 years

Migrant has been in US 6-10 years

Migrant has been in US 11-15 years

\begin{tabular}{|c|c|c|c|}
\hline \multicolumn{4}{|c|}{ Treatment group } \\
\hline 0 & 1 & 2 & 3 \\
\hline 0.29 & 0.28 & 0.33 & 0.29 \\
\hline 0.58 & 0.63 & 0.67 & 0.64 \\
\hline 0.53 & 0.52 & 0.55 & 0.58 \\
\hline 0.16 & 0.10 & 0.09 & 0.11 \\
\hline 0.07 & 0.05 & 0.02 & 0.04 \\
\hline 0.24 & 0.32 & 0.34 & 0.27 \\
\hline 0.49 & 0.47 & 0.44 & 0.52 \\
\hline 0.39 & 0.41 & 0.44 & 0.37 \\
\hline 0.12 & 0.12 & 0.12 & 0.11 \\
\hline 5.59 & 5.58 & 5.75 & 5.73 \\
\hline 0.17 & 0.17 & 0.14 & 0.21 \\
\hline 30,297 & 41,590 & 29,034 & 28,447 \\
\hline 34,996 & 50,717 & 34,425 & 39,389 \\
\hline 8.46 & 8.03 & 8.63 & 8.56 \\
\hline 31.08 & 32.21 & 31.10 & 31.00 \\
\hline 5,335 & 5,532 & 4,855 & 5,197 \\
\hline 2,731 & 3,097 & 1,907 & 2,819 \\
\hline 0.00 & 0.00 & 0.01 & 0.01 \\
\hline 4.87 & 5.21 & 4.98 & 4.50 \\
\hline 0.57 & 0.58 & 0.62 & 0.62 \\
\hline 0.11 & 0.10 & 0.08 & 0.08 \\
\hline 0.25 & 0.20 & 0.24 & 0.25 \\
\hline 0.20 & 0.23 & 0.17 & 0.16 \\
\hline 0.16 & 0.14 & 0.15 & 0.14 \\
\hline 0.05 & 0.07 & 0.05 & 0.03 \\
\hline 0.53 & 0.50 & 0.45 & 0.55 \\
\hline 0.60 & 0.71 & 0.67 & 0.67 \\
\hline 0.62 & 0.60 & 0.63 & 0.66 \\
\hline 0.37 & 0.37 & 0.31 & 0.36 \\
\hline 0.44 & 0.44 & 0.44 & 0.47 \\
\hline 273 & 684 & 336 & 584 \\
\hline 2,988 & 3,371 & 3,474 & 3,525 \\
\hline 0.64 & 1.03 & 0.98 & 1.27 \\
\hline 161 & 204 & 233 & 344 \\
\hline
\end{tabular}

\begin{tabular}{|c|c|c|c|c|}
\hline \multicolumn{4}{|c|}{ P-value of F-test .. } & \multirow[b]{2}{*}{$\begin{array}{c}\text { Num. of } \\
\text { Obs. }\end{array}$} \\
\hline $\begin{aligned} \mathrm{T} 0 & =\mathrm{T} 1=\mathrm{T} 2 \\
& =\mathrm{T} 3\end{aligned}$ & $\mathrm{~T} 1=\mathrm{T} 0$ & $\mathrm{~T} 2=\mathrm{T} 0$ & $\mathrm{~T} 3=\mathrm{T} 0$ & \\
\hline 0.761 & 0.903 & 0.408 & 0.941 & 508 \\
\hline 0.553 & 0.408 & 0.150 & 0.333 & 508 \\
\hline 0.790 & 0.940 & 0.750 & 0.408 & 508 \\
\hline 0.438 & 0.219 & 0.102 & 0.305 & 508 \\
\hline 0.168 & 0.570 & 0.062 & 0.255 & 508 \\
\hline 0.251 & 0.179 & 0.077 & 0.642 & 508 \\
\hline 0.607 & 0.748 & 0.413 & 0.666 & 508 \\
\hline 0.656 & 0.809 & 0.445 & 0.675 & 508 \\
\hline 0.998 & 0.897 & 0.924 & 0.971 & 508 \\
\hline 0.975 & 0.989 & 0.725 & 0.778 & 508 \\
\hline 0.465 & 0.930 & 0.520 & 0.381 & 508 \\
\hline 0.786 & 0.420 & 0.715 & 0.635 & 490 \\
\hline 0.385 & 0.258 & 0.859 & 0.303 & 508 \\
\hline 0.698 & 0.453 & 0.744 & 0.863 & 491 \\
\hline 0.600 & 0.292 & 0.988 & 0.937 & 505 \\
\hline 0.583 & 0.758 & 0.397 & 0.821 & 508 \\
\hline 0.138 & 0.630 & 0.141 & 0.892 & 469 \\
\hline 0.224 & 1.000 & 0.157 & 0.316 & 505 \\
\hline 0.095 & 0.271 & 0.665 & 0.187 & 508 \\
\hline 0.811 & 0.862 & 0.427 & 0.459 & 508 \\
\hline 0.831 & 0.773 & 0.461 & 0.411 & 508 \\
\hline 0.747 & 0.363 & 0.851 & 0.973 & 508 \\
\hline 0.468 & 0.481 & 0.540 & 0.467 & 508 \\
\hline 0.960 & 0.651 & 0.758 & 0.615 & 508 \\
\hline 0.507 & 0.617 & 0.993 & 0.372 & 508 \\
\hline 0.419 & 0.733 & 0.237 & 0.724 & 508 \\
\hline 0.330 & 0.066 & 0.214 & 0.239 & 508 \\
\hline 0.808 & 0.805 & 0.773 & 0.510 & 508 \\
\hline 0.715 & 0.903 & 0.374 & 0.905 & 508 \\
\hline 0.935 & 0.928 & 0.968 & 0.578 & 508 \\
\hline 0.392 & 0.147 & 0.745 & 0.234 & 428 \\
\hline 0.501 & 0.293 & 0.221 & 0.179 & 426 \\
\hline 0.094 & 0.109 & 0.133 & 0.016 & 508 \\
\hline 0.558 & 0.712 & 0.611 & 0.162 & 508 \\
\hline
\end{tabular}

aseline survey variables

Migrant's years in the US

Migrant has El Salvador bank account

Migrant's annual income (US\$)

Migrant's household's annual income (US\$)

Migrant's years of education

Migrant's age

Migrant's annual remittances sent (US\$)

Migrant's total hh savings balance (US\$)

Migrant is US citizen

Migrant hh size in U.S.

Migrant is married or partnered

Past experience with direct payments

Sent funds to El Salvador for others to administe

Interested in direct payments to increase control

Aware of disagreements with recipients over remittance uses

Have had disagreements with recipients over remittance uses

Demand for control (union of above five indicators)

Correct answer to compound interest question

Correct answer to inflation question

Correct answer to mutual fund question

Tracks spending and budgets expenses

Baseline variables from El Salvador household survey

Recipient's total hh savings balance (US\$)

Recipient's annual remittances received (US\$)

Pre-treatment savings at partner bank

Quartic root of savings balance, average over 12 months prior to treatment

233

0.558

0.712

0.611

Notes -- Table presents means of key variables for each treatment group prior to treatment, for observations that have valid savings data in migrant follow-up survey. See previous table for other notes. 


\section{Appendix Table 4: Impact of treatments on savings in accounts at partner bank in follow-up sample $(\mathrm{N}=508)$}

(Ordinary least-squares estimates)

Dependent variable: Savings balance (US\$), average over 12 months post-treatment, in accounts of given type
Cuenta Unidos accounts (in Ahorro Directo accounts Other accounts (in name of In total across all accounts name of someone in El (in name of migrant only) migrant or primary Salvador) remittance recipient)

\section{Panel A (quartic root)}

Treatment 3 (joint account + migrant-only account)

Treatment 2 (joint account)

(a)

(b)

(c) $(\mathrm{d})=(\mathrm{a})+(\mathrm{b})+(\mathrm{c})$

Treatment 1 (PRR account only)

Constant

$\begin{array}{cccccccc}0.432^{* * *} & 0.470^{* * *} & 0.322^{* * *} & 0.356^{* * *} & 0.813^{* * *} & 0.686^{* * *} & 1.233^{* * *} & 1.163^{* * *} \\ (0.164) & (0.174) & (0.122) & (0.134) & (0.243) & (0.222) & (0.278) & (0.271) \\ 0.208 & 0.316^{* *} & -0.055 & -0.042 & 0.515^{* *} & 0.471^{* *} & 0.538^{* *} & 0.612^{* *} \\ (0.143) & (0.145) & (0.055) & (0.068) & (0.205) & (0.203) & (0.237) & (0.237) \\ 0.027 & 0.046 & -0.020 & -0.021 & 0.367 * & 0.321 & 0.364 & 0.319 \\ (0.107) & (0.104) & (0.065) & (0.079) & (0.202) & (0.204) & (0.223) & (0.228) \\ 0.225^{* * *} & 0.078 & 0.055 & 0.273 & 0.470^{* * *} & 0.197 & 0.750^{* * *} & 0.369 \\ (0.087) & (0.523) & (0.055) & (0.199) & (0.112) & (1.094) & (0.143) & (0.980)\end{array}$

Marketer fixed effects

Observations

R-squared

Y

\section{Y}

508

0.019

508

0.130

508

\section{Y}

\section{Y}

Y

P-value of F-test: equality of ...

Treatment 3 \& 2 coeffs.

Treatment 3 \& 1 coeffs.

Treatment $2 \& 1$ coeffs.

0.212
0.008
0.166

\subsection{0}

0.010

0.078

0.001

0.003

0.316

508

0.123

508

508

0.020

0.126

508

0.039

508

Mean of dep. var. in comparison group

0.225

0.000
0.002
0.672

0.278

0.107

0.413

0.161

0.023

0.004

0.503

0.064

0.004

0.543

0.529

0.274

0.470

0.750

\section{Panel B (in dollars)}

Treatment 3 (joint account + migrant-only account)

Treatment 2 (joint account)

0.055

135.173

(117.167)

89.403

188.150

(148.999)

(69.562)

140.727*

$-15.839$

(12.540)

(82.795)

$-8.065$

(34.131)

19.067

431.676*

(246.722)

31.361

(24.064)

$-12.886$

(12.830)

$-10.501$

(13.042)

12.886

(12.830)

\section{Y}

508

0.006

508

0.067

508

0.017

0.739

0.147

0.088

0.031
0.042
0.316

0.030

0.046

0.867

0.599

0.052

0.259

389.601***

0.194

0.014

12.886

$312.574^{* * *}$

$556.134^{* * *}$

(175.701)

363.312**

(165.567)

83.154

(61.365)

$65.192 * * *$

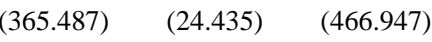

Mean of dep. var. in comparison group

\section{Y}

\section{Y}

\section{8}

0.125

508

508

0.020

0.107

$\begin{array}{lll}0.366 & 0.418 & 0.277 \\ 0.060 & 0.011 & 0.010 \\ 0.406 & 0.106 & 0.123 \\ & & \\ 33.239 & & 65.192\end{array}$

Robust standard errors in parentheses. * significant at 10\%; ** significant at 5\%; *** significant at $1 \%$

Notes: Dependent variables are averaged over end-of-month balances in US dollars. See Table 2 for other notes. 


\section{Appendix Table 5: Impact of treatments on joint account savings reported by migrant in non-partner banks in follow-up survey}

(Ordinary least-squares estimates)

Dependent variable: Savings not at partner bank ...

... in joint accounts, migrant and primary remittance recipient

(1)

$\begin{array}{cc}0.059 & 0.120^{*} \\ (0.047) & (0.072) \\ 0.027 & 0.215^{* *} \\ (0.023) & (0.106) \\ 0.113 & 0.153 \\ (0.104) & (0.111) \\ & \\ Y & Y \\ & \\ 508 & 508 \\ 0.044 & 0.070 \\ & \\ & \\ 0.317 & 0.413 \\ 0.578 & 0.787 \\ 0.343 & 0.659\end{array}$

\section{Panal A (quartic root)}

Treatment 3 (joint account + migrant-only account)

Treatment 2 (joint account)

Treatment 1 (PRR account only)

Control variables

Observations

R-squared

P-value of F-test: equality of ...

Treatment 3 \& 2 coeffs.

Treatment $3 \& 1$ coeffs.

Treatment $2 \& 1$ coeffs.

\section{Panal B (in dollars)}

Treatment 3 (joint account + migrant-only account)

Treatment 2 (joint account)

Treatment 1 (PRR account only)

Control variables

Observations

R-squared

P-value of F-test: equality of ...

Treatment 3 \& 2 coeffs.

Treatment $3 \& 1$ coeffs.

Treatment $2 \& 1$ coeffs.

Robust standard errors in parentheses. * significant at 10\%; ** significant at 5\%; *** significant at 1\% Notes: Dependent variable is stock of savings in US dollars. See Table 4 for other notes. 